\title{
The association between systemic autoimmune disorders and epilepsy and its clinical implications
}

Running Title: Systemic autoimmune disorders and epilepsy Claude Steriade ${ }^{1}$, Maarten Titulaer ${ }^{2}$, Annamaria Vezzani ${ }^{3}$, Josemir W Sander ${ }^{4-5}$, Roland D Thijs ${ }^{4-6}$

1. Department of Neurology, New York University School of Medicine, New York, NY, USA.

2. Department of Neurology, Erasmus University Medical Center, Rotterdam, Netherlands.

3. Department of Neuroscience, Istituto di Ricerche Farmacologiche Mario Negri IRCCS, Milan, Italy.

4. NIHR University College London Hospitals Biomedical Research Centre, UCL Queen Square Institute of Neurology, London WC1N 3BG，\& Chalfont Centre for Epilepsy, Chalfont St Peter SL9 0RJ, Bucks, UK.

5. Stichting Epilepsie Instellingen Nederland - (SEIN), Heemstede, Netherlands

6. Department of Neurology, Leiden University Medical Centre, Leiden, Netherlands.

Corresponding author:

Roland D. Thijs MD PhD

Stichting Epilepsie Instellingen Nederland (SEIN)

P.O Box 540; 2130 AM Hoofddorp, Netherlands

Phone: +3123558 8948

Fax: +3123558 8159.

E-mail address: rthijs@ sein.nl

Abstract: 197 words

Manuscript: 6131 words (including boxes, table)

3 tables, 3 boxes, 1 figure 


\section{$\underline{\text { Abstract }}$}

Systemic autoimmune disorders (SADs) happen more frequently in people with epilepsy than in the general population, suggesting shared disease mechanisms. The risk of epilepsy is elevated across the spectrum of SADs but is highest in systemic lupus erythematosus and type 1 diabetes mellitus. Vascular and metabolic factors are the most important mediators between SAD and epilepsy. Systemic immune dysfunction can also affect neuronal excitability, not only through innate immune activation and blood-brain barrier dysfunction in most epilepsies but also adaptive immunity in autoimmune encephalitis. The presence of systemic autoimmune disorders in subjects with acute seizures warrants evaluation for infectious, vascular, toxic and metabolic causes of acute symptomatic seizures, but clinical signs of autoimmune encephalitis should not be missed. Immunosuppressive medications may have antiseizure properties and trigger certain drug interactions with antiseizure treatments. A better understanding of mechanisms underlying the co-existence of epilepsy and systemic autoimmune disorders is needed to guide new antiseizure and antiepileptogenic treatments. This review aims to summarize the epidemiological evidence for systemic autoimmune disorders as comorbidities of epilepsy, explore potential immune and non-immune mechanisms, and provide practical implications on diagnostic and therapeutic approach to epilepsy in those with comorbid systemic autoimmune disorders.

Keywords: Comorbidities, acute symptomatic seizures, seizures, autoimmunity Abbreviations: antiphospholipid antibodies (APLA), blood-brain-barrier (BBB), central nervous system (CNS), cerebrospinal fluid (CSF), damage associated molecular patterns (DAMPs), diabetic ketoacidosis (DKA), glutamic acid decarboxylase (GAD65), hippocampal sclerosis (HS), inflammatory bowel disease (IBD), leucine-rich glioma-inactivated protein 1 (LGI1), N- 
Steriade et al. 2020 Systemic autoimmune disorders and epilepsy

methyl-D-aspartate receptor (NMDAR), posterior reversible encephalopathy syndrome (PRES), steroid responsive encephalopathy associated with autoimmune thyroiditis (SREAT), systemic autoimmune disorders (SADs), systemic lupus erythematosus (SLE), tumour necrosis factor (TNF), type 1 diabetes mellitus (T1DM), vagus nerve stimulation (VNS). 


\section{$\underline{\text { Introduction }}$}

Comorbidities impose a heavy burden on people with epilepsy and provide opportunities for improving knowledge of disease mechanisms (Keezer et al., 2016b). The investigation of epilepsy comorbidities was designated an epilepsy research benchmark (NINDS, 2014). While psychiatric comorbidities have long been recognised as an important issue, systemic comorbidities have also recently become topical. Several systemic conditions, such as cardiovascular disease, peptic ulcer, cancer, and arthritis, are more common in people with epilepsy than in the general population (Keezer et al., 2016b). There is increasing evidence that systemic autoimmune disorders (SADs) are associated with chronic epilepsy and not just with acute symptomatic seizures (Amanat et al., 2018).

The epidemiological association between SADs and epilepsy provides an opportunity to improve knowledge about the role of inflammation in epileptogenesis, which has gained increasing attention as a potential target for a disease-modifying therapeutic effect (Devinsky et al., 2013; Vezzani et al., 2019). A plausible epidemiological link recently came from a large cohort study which showed an elevated prevalence of epilepsy amongst people with SADs (OR 3.8; 95\% CI 3.6-4.0) (Ong et al., 2014). Other studies have replicated these findings in individual SADs, while some failed to confirm this association (Lossos et al., 1995; Pengiran Tengah et al., 2004; Hanly et al., 2005; O'Connell et al., 2008). Probing epidemiological links carries the potential to improve the understanding of common mechanisms, which could in turn instruct the development of novel treatment approaches to epilepsy.

In this narrative review, recent epidemiological evidence for the association between individual SADs and epilepsy, and its clinical correlates are discussed. We then explore the role of vascular, metabolic, and genetic mediators in the association of epilepsy with individual SADs 
and outline evidence for the impact of systemic immunological dysfunction on the brain in human epilepsy and experimental models of SADs. We synthesize these findings into a diagnostic approach for people with SADs presenting with seizures, and outline treatment implications including drug-drug interactions and the impact of treatments of one comorbidity on the other.

\section{Individual SADs and epilepsy}

Multiple SADs have been associated with an increased risk of epilepsy, yet the heterogeneity of the comorbid seizure disorders suggests that each entails different potential mechanisms for seizure development. Some systemic autoimmune conditions do not have to date a clear reported association with epilepsy (e.g. scleroderma, giant cell arteritis, and vitiligo). This may stem from a heterogeneous association between epilepsy and only certain SADs, or from the lack of appropriately powered studies to evaluate the association in these conditions. We focus here on those SADs with sufficient reports to support an association but, whenever relevant, highlight conflicting data on the presence of a comorbidity link between SADs and epilepsy. With the exception of diseases affecting only adults such as rheumatoid arthritis, the review encompasses reports from adult and paediatric populations. The conceptual distinction between chronic epilepsy, an enduring predisposition to recurrent unprovoked seizures (Fisher et al., 2005), and acute symptomatic seizures, a mere symptom of an underlying brain insult (Beghi et al., 2010), carries practical implications for the interpretation of reports supporting an association between seizures and SADs. We highlight throughout this review whether reports support an association between an SAD and acute symptomatic seizures, epilepsy, or both. We begin with rheumatological disorders (Table 1), followed by endocrinological disorders (Table 2), then 
gastrointestinal disorders (Table 3). In each section, we introduce potential mechanisms of seizures in each disease section, then explore these in further detail in the next section, on comorbidity mechanisms.

\section{$\underline{\text { Rheumatological disorders }}$}

\section{Systemic lupus erythematosus}

About one third of people with SLE develop neuropsychiatric lupus, a broadly defined condition in which neurological and psychiatric symptoms co-occur with SLE without other clear precipitants (Lisnevskaia et al., 2014). Neuropsychiatric lupus accounts for a significant portion of the association between seizures and SLE as acute symptomatic seizures occur in up to one fourth of all cases (Table 1) (Magro-Checa et al., 2017). Indeed, seizures in SLE are associated with worse systemic disease severity (Andrade et al., 2008) and central nervous system (CNS) involvement, such as psychiatric comorbidity (Tsai, 2014), prior stroke (Andrade et al., 2008; Tsai, 2014), and antiphospholipid antibodies (APLA) (Islam et al., 2018). In large cohort studies, the majority of seizures occurred in close proximity to the diagnosis of SLE, and often resolved without long-term antiseizure medication, suggesting that the diagnosis of epilepsy did not apply (Hanly et al., 2012a). Subjects with acute symptomatic seizures attributed to SLE are less likely to be followed by recurrent seizures (i.e. epilepsy) than those experiencing unexplained seizures, not attributed to neuropsychiatric lupus (Hanly et al., 2012a). Conversely, mesial temporal epilepsy accounts for above one third of chronic epilepsy in the setting of SLE and may rarely precede the diagnosis of SLE (Toyota et al., 2013).

The association of SLE with seizures may be accounted for by vascular mediators, but also immune mechanisms, through antineuronal antibodies and cross reactivity of systemic 
autoantibodies with neural antigens. These mechanisms are discussed below, in the

"Comorbidity mechanisms" section.

\section{Rheumatoid arthritis}

Two reports from administrative databases suggest an increased risk of epilepsy in people with rheumatoid arthritis (Table 1) (Ong et al., 2014; Chang et al., 2015). The risk appeared to be lower and only marginally increased in the report which adjusted for comorbidities (including vascular risk factors such as hypertension and diabetes), thus indicating that vascular factors are important mediators in the relationship between rheumatoid arthritis and epilepsy (Chang et al., 2015).

\section{$\underline{\text { Endocrinological disorders }}$}

\section{Type 1 diabetes mellitus}

Four large scale population-based studies using administrative databases have shown that in those with newly diagnosed T1DM, the risk of developing seizures is up to three times greater than in controls (Table 1) (Ong et al., 2014; Fazeli Farsani et al., 2015; Chou et al., 2016; Dafoulas et al., 2017). The association may be artifactual as the peak age of onset of T1DM and epilepsy coincide (DiMeglio et al., 2018; Thijs et al., 2019). One may also speculate that misdiagnosis of hypoglycaemic events as seizures might have confounded large-scale epidemiological data. It is, however, unlikely that selection bias or misdiagnosis fully explains the association in view of the impact of T1DM on the developing brain (Cameron et al., 2019). The onset of T1DM usually precedes the onset of epilepsy (Mastrangelo et al., 2019), but detailed epilepsy profiles in T1DM are still lacking. A small scale clinical cohort study suggested that T1DM is more frequent in people with refractory epilepsy and epilepsy of unknown cause (Keezer et al., 2015). 
Temporal trends indicate that the incidence of epilepsy in T1DM has decreased over the past decades (Sillanpaa et al., 2019). The incidence decline might be explained by improved glycemic control, which would support metabolic derangements as an important driver in the association between epilepsy and T1DM. Glutamic acid decarboxylase 65 (GAD65) antibodies are another attractive shared risk factor for the development of systemic and central nervous system (CNS) disease in T1DM and are discussed in the "Immune mediators" section below.

\section{Hashimoto's thyroiditis}

People with Hashimoto's thyroiditis have a higher risk of seizures (Table 1) (Ong et al., 2014), and may present with Hashimoto's encephalopathy, a rare condition associated with an increased risk for seizures and thyroiditis with elevated levels of anti-thyroid antibodies (Laurent et al., 2016). The term "steroid responsive encephalopathy associated with autoimmune thyroiditis" (SREAT) has been suggested to include treatment response as an additional criterion. Acute symptomatic seizures are the most common presenting symptom and occur in $47 \%$ of all cases (Laurent et al., 2016). The existing body of knowledge is limited by the lack of standardized diagnostic criteria and precedes the availability of antineuronal antibodies. Current diagnostic criteria require the absence of well characterised antineuronal antibodies in serum and cerebrospinal fluid (CSF) to make a diagnosis of Hashimoto's encephalopathy (Graus et al., 2016). SREAT should, however, be suspected when people with a history of thyroiditis present with seizures and an unexplained encephalopathy. Anti-thyroid peroxidase (TPO) antibodies have been a prerequisite for SREAT (Montagna et al., 2016), but these antibodies lack specificity and occur in up to $13 \%$ of the population (Frohlich and Wahl, 2017), thus restricting their clinical use in people without a history of clinical or subclinical thyroid dysfunction (Graus et al., 2016). One small study reported a correlation between high anti-TPO antibodies at the 
time of diagnosis and favourable outcome with immune-targeted treatment, suggesting that titres may be helpful in predicting response, although (limited) antineuronal antibody testing was only performed in some of the patients (Litmeier et al., 2016).

\section{Gastrointestinal disorders}

\section{Coeliac disease}

The strongest evidence of a relationship between coeliac disease and subsequent epilepsy stemmed from a Swedish cohort study of 28,885 subjects with biopsy-verified coeliac disease, showing a 1.42 fold risk of developing epilepsy after a diagnosis of coeliac disease over a mean follow-up of ten years (Ludvigsson et al., 2012b). The risk of comorbid epilepsy appeared to be higher in children (OR 16.7) compared to adults (OR 2.5) with coeliac disease (Table 1) (Ong et al., 2014). Small scale clinical studies suggested that adults with temporal lobe epilepsy with hippocampal sclerosis (HS) and children with occipital epilepsy might have a higher risk of comorbid coeliac disease (Julian et al., 2018). It has been suggested that comorbid coeliac disease can present without gastrointestinal symptoms in up to $40 \%$ of people with epilepsy (Julian et al., 2018). This figure, however, was based on studies with positive antibodies only, without a diagnosis confirmed by duodenal biopsy, which may overestimate the diagnosis of comorbid coeliac disease and include the controversial entity of gluten sensitivity (Julian et al., 2018). While one uncontrolled study reported an association between temporal lobe epilepsy and positive coeliac antibodies without confirmatory duodenal biopsy and gastrointestinal symptoms (Peltola et al., 2009), another study failed to show an association with coeliac antibodies in children without gastrointestinal symptoms, when compared to a control population without epilepsy (Giordano et al., 2009). The association of epilepsy with "occult coeliac disease" without confirmatory biopsy findings is therefore unclear. 
Gut dysfunction is one potential mediator of seizures in the setting of coeliac disease. Another potential mechanism is the cross reactivity of systemic antibodies (e.g. transglutaminase antibodies) to neural antigens - this is discussed below, in the "Immune mediators" section.

\section{Inflammatory bowel disease}

Case-control studies using administrative databases suggested an increased risk of epilepsy in inflammatory bowel disease (IBD) (Table 1) (Virta and Kolho, 2013; Ong et al., 2014). One large case series of people with IBD, however, systematically excluded acute symptomatic seizures, and failed to identify subjects with epilepsy (Lossos et al., 1995). Acute symptomatic seizures due to medication side effects (e.g. calcineurin inhibitor toxicity), metabolic disturbance (e.g. hypomagnesemia) and stroke may account for a significant proportion of seizures associated with IBD. It remains thus uncertain whether IBD is actually associated with an increased risk for epilepsy.

\section{Comorbidity mechanisms}

\section{$\underline{\text { Immune mediators }}$}

Innate immune dysfunction exists across the spectrum of human epilepsies and represents an attractive hypothetical link to explain the comorbidity of SADs and epilepsy. Brain specimens of people with focal epilepsy who underwent epilepsy surgery (Vezzani et al., 2019) and of people who died after status epilepticus (Pauletti et al., 2017) exhibit innate immunity activation, similar to that shown in experimental models of acquired epilepsy. Several innate immunityassociated inflammatory mediators promote seizure generation by reducing neuronal excitability threshold (Box 1, Figure 1A) (Vezzani et al., 2019). Specifically, the pro-inflammatory cytokine interleukin (IL)-1 $\beta$ is increased in brains of people with focal cortical dysplasia type 2, temporal lobe epilepsy, and tuberous sclerosis complex (Aronica and Crino, 2014). In those with epilepsy 
following traumatic brain injury, serum and CSF IL-1 $\beta$ levels carry a dose-dependent effect on seizure risk (Diamond et al., 2014). Damage associated molecular patterns (DAMPs), involved in the initiation of the innate immunity response, have also been found to be increased in brain tissue from individuals following epilepsy surgery (Zhang et al., 2018). Systemic immune activation during gestation or post-natal development also predisposes animals to develop chronically reduced seizure thresholds, through central cytokines such as $\mathrm{IL}-1 \beta$, tumour necrosis factor (TNF) and IL-6 (Pineda et al., 2013). This finding in animal models has been validated by a report showing that children of mothers but not fathers, with rheumatoid arthritis have an increased risk of childhood epilepsy (Rom et al., 2016). The role of innate immune dysfunction in precipitating seizures has been validated in animal models of SADs. T1DM models exhibit BBB dysfunction and increased blood cytokine levels, which may lower seizure threshold (Yorulmaz et al., 2015). Altered brain excitability and reduced seizure threshold can also be evoked by induction of experimental colitis in mice, through brain inflammatory cytokine production and enhanced BBB permeability to small molecules (Nyuyki and Pittman, 2015).

In specific epilepsy syndromes, there is an additional role for adaptive immunity, as evidenced by the brain infiltration of immune cells, characteristic of encephalitis (Bauer and Bien, 2016) (Figure 2B). For example, adaptive immunity and innate immunity coexist in Rasmussen's encephalitis, in which CD3+/CD8+ T-cells and innate immunity-related inflammatory cytokines (e.g. IL-6 and IL-1 $\beta$ ) and DAMPs (e.g. High Mobility Group Box 1 and Toll-like receptors) can be identified (Varadkar et al., 2014). Classical paraneoplastic encephalitis with antibodies against intracellular proteins, such as $\mathrm{Hu}$ or CV2, exhibits a similar cytotoxic T-cell response (Dalmau and Graus, 2018). These antibodies are biomarkers for an adaptive immunity response, as the neuronal damage is caused by $\mathrm{T}$-cell inflammation (Dalmau 
and Graus, 2018). Conversely, antibodies against extracellular synaptic or membrane proteins, such as N-methyl-D-aspartate receptor (NMDAR) and leucine-rich glioma-inactivated protein 1 (LGI1), have direct functional effects (Ohkawa et al., 2013; Planaguma et al., 2016). Biopsies in autoimmune encephalitis usually show only mild to moderate lymphocyte infiltration or complement deposition (Bauer and Bien, 2016). In anti-LGI1 encephalitis, some T-cell activation is also observed (Bauer and Bien, 2016), as well as progressive atrophy, indicating neuronal damage by non-IgG4-mediated pathways (Arino et al., 2016; Thompson et al., 2018).

While antibody-mediated encephalitis manifests with acute symptomatic seizures (Bien and Holtkamp, 2017), the prevalence of antineuronal antibodies in people with chronic epilepsy is less clear, as the proportion of those with positive antibodies ranged from three to $20 \%$ (Brenner et al., 2013; Borusiak et al., 2016; Wright et al., 2016; Dubey et al., 2017; Nobrega-Jr et al., 2018; de Bruijn et al., 2019a). Antibody positivity also occurs in up to one third of people in status epilepticus of unknown cause (Gaspard et al., 2015). The interpretation of these studies is challenging due to the variability in inclusion criteria, such as the lack of explicit exclusion of people with overt autoimmune encephalitis phenotype who may in fact have acute symptomatic seizures rather than epilepsy, and lack of rigorous antibody testing methodology (Leypoldt et al., 2017). A personal history of SAD was described in about half of a small cohort with autoimmune encephalitis and seizures (Quek et al., 2012). In a chronic epilepsy cohort systematically tested for antineuronal antibodies, about half of antibody positive people had a comorbid SAD, compared to about $9 \%$ of those who were antibody negative. In this cohort, of the nine antibody positive epilepsy patients who also had an SAD, eight carried GAD65 antibodies, while another had a cell surface antibody(de Bruijn et al., 2019a). If a true association between epilepsy and antineuronal antibodies in the context of SADs exists, a pure 
immune mechanism may not only precipitate seizures but also cause brain lesions, such as hippocampal sclerosis (Carreno et al., 2017; Finke et al., 2017; Miller et al., 2017), which may in turn be a substrate of ongoing seizures. Immune and structural causes of epilepsy may therefore coexist in subjects with antineuronal antibodies and recurrent seizures.

Nevertheless, the association between antineuronal antibodies and epilepsy in people with SADs has been examined in the setting of a number of SADs, including T1DM and SLE. The common association between T1DM, other SADs, and autoimmune encephalitis, with GAD65 antibodies (Muñoz-Lopetegi et al., 2020) suggests a possible role for autoimmunity in mediating this comorbidity, but there are numerous caveats to this hypothesis. Firstly, approximately $85 \%$ of people with newly-diagnosed T1DM and about a third of those with a duration of more than five years have GAD65 antibodies, which far exceeds the prevalence of epilepsy (DiMeglio et al., 2018). Secondly, only very high titre antibodies in serum are associated with neurological dysfunction, including epilepsy (Ganelin-Cohen et al., 2016). As most clinical laboratories perform GAD65 antibodies for T1DM and do not necessarily test samples at a dilution suitable to accurately determine GAD65 antibody titers, particular caution needs to be taken in the interpretation of those results. Thirdly, the response to immunotherapy in people with serological GAD65 antibodies and neurological disease is variable and often poor (Malter et al., 2015). Fourthly, serum-CSF pairs are critical in GAD65 encephalitis (Bien and Holtkamp, 2017). It is possible that in some cases serum antibodies enter the brain compartment by diffusion and thus cause disease, but most studies show intrathecal synthesis of the antibodies in people with CNS disease (Gresa-Arribas et al., 2015). Lastly, it is still unknown how GAD65 antibodies may cause epilepsy. Some experimental models have supported a pathogenic role for GAD65 antibodies, which when directly administered lead to cerebellar neuronal loss (Mitoma 
et al., 2017). Direct administration of GAD65 antibodies to hippocampal slices did not, however, lead to neurophysiological changes, thus questioning their pathophysiological relevance to GAD65-antibody associated epilepsy (Hackert et al., 2016).

Antineuronal antibodies have also been assessed in the setting of SLE. One tenth of a highly selected small cohort of people with epilepsy and SLE were reported to harbour antineuronal antibodies to known antigens in serum, with a larger proportion also carrying antibodies to unknown neuropil antigens, which are of unclear clinical significance (Karaaslan et al., 2017).

Cross-reactivity between neural antigens and systemic antibodies found across SADs may be another mediator of epilepsy in SADs. For example, anti-transglutaminase antibodies seen in people in coeliac disease cross-react with neural antigens in the cerebellum and brainstem and can induce cerebellar dysfunction in animal models (Boscolo et al., 2010). These findings have yet to be reproduced in experimental models relevant to epilepsy. Cross-reactivity between systemic antibodies and neural antigens was also demonstrated in the setting of SLE. Anti-double stranded DNA cross-reacts with the extracellular domain of NR2 subunits of the NMDA receptor, and NR2 antibodies lead to an inflammatory cascade and apoptosis in animal models (DeGiorgio et al., 2001). The association between NR2 antibodies and neuropsychiatric lupus was replicated in one (Yang et al., 2017) but not in another study of people with SLE, perhaps owing to limited specificity with the use of ELISAs (Hanly et al., 2012a). Lastly, systemic antibodies (e.g. antiphospholipid antibodies) may have direct effects on cytokine production and neuronal excitability (Fleetwood et al., 2018).

\section{$\underline{\text { Non-immune mediators }}$}


Vascular disease may be an epilepsy mediator in the setting of IBD, T1DM, SLE and rheumatoid arthritis and lead to focal epilepsy. For instance, vascular comorbidities increase the risk of seizures in those with rheumatoid arthritis (Chang et al., 2015). Cerebrovascular disease is also more frequent in T1DM (de Ferranti et al., 2014) and IBD (Kohoutova et al., 2015) than in the general population, but its relationship with epilepsy has not been assessed. Cerebral thrombosis may also mediate the development of epilepsy in SLE through the effects of APLA antibodies (e.g. anticardiolipin, lupus anticoagulant, beta-2 glycoprotein) on the coagulation cascade, leading to ischemic brain insults (Fleetwood et al., 2018). Vasculitis is another rare but treatable complication of SADs, such as SLE, and can lead to cerebral ischemia (Barile-Fabris $e t$ $a l ., 2014)$. Ischemia is known to induce epileptogenesis in animal models, and depending on the nature of the underlying cerebrovascular disease, 3 to $30 \%$ of people who suffer a stroke will go on to develop epilepsy (Pitkanen et al., 2016). Whether the risk for post stroke epilepsy is increased in people with SADs is currently unknown.

Another potential mediator of epilepsy is neuronal injury caused by metabolic disturbance in the context of T1DM. Indeed, hyperglycaemia, diabetic ketoacidosis and recurrent hypoglycaemia have all been associated with brain volume loss and cognitive impairment (Cameron et al., 2019). Diabetic ketoacidosis (DKA) has also been linked to a higher risk of epilepsy (Mastrangelo et al., 2019) and has been associated with morphologic and functional brain changes (Cameron et al., 2014). Diffusion-weighted imaging have suggested a role for abnormal cerebral perfusion in animal models of DKA (Glaser et al., 2012) and hypoglycaemia (Tong et al., 2019) in precipitating brain injury. Permanent injury of the CA1, subiculum and dentate gyrus of the hippocampus have been hypothesized to correlate with reduced 
neurogenesis, due to progenitor cell loss in the dentate gyrus in animal models of hypoglycaemia (Suh et al., 2005).

Gut dysfunction may play a role in mediating seizures through nutrient deficiency or microbiome alterations in the setting of autoimmune gastrointestinal disorders. Specific nutrient deficiencies which could lead to seizures include vitamin B6 and folate deficiency. Outside the realm of genetically determined pyridoxine-dependent seizures presenting in infancy, vitamin B6 deficiency related acute symptomatic seizures have been reported in pregnancy (SchulzeBonhage et al., 2004) and in adults with alcohol dependence, with improvement after B6 supplementation (Gerlach et al., 2011). Reports of acquired folate deficiency related seizures improving with folate supplementation are still lacking. The rare radiologic syndrome of cerebral occipital calcifications and epilepsy seen among people with coeliac disease in the Mediterranean basin (Gobbi et al., 1992; Julian et al., 2018) closely resembles that of cerebral folate deficiency, which raises the possibility of folate malabsorption as a mediator of brain calcifications in coeliac disease (Masingue et al., 2019). The role of nutrient deficiency in mediating seizures was, however, challenged by the finding that persistent villous atrophy in coeliac disease correlates with a reduced epilepsy risk, the opposite of what might be expected if nutrient deficiency was a driver in the development of epilepsy (Kurien et al., 2018). Alterations in the gut microbiome are common in coeliac disease and is an unexplored avenue of research which may explain the relationship between coeliac disease and epilepsy (Lebwohl et al., 2018). Lastly, genetic factors may be a shared disease mechanism between SADs and epilepsy. A recent genome-wide linkage analysis suggested common genetic polymorphisms between SLE and epilepsy (ILAE Consortium on Complex Epilepsies, 2018). HLA haplotypes (DQ2) may also be common to both diseases, for example in the case of mesial temporal epilepsy and 
coeliac disease (Lebwohl et al., 2018). Shared genetic risk factors in T1DM have largely been anecdotal and restricted to families with epilepsy and neonatal diabetes mellitus carrying certain gene mutations (Poulton et al., 2011; Duong et al., 2012). Shared HLA profiles might also explain the association between seizures and SADs as distinct haplotypes have been reported in some syndromes causing autoimmune encephalitis and epilepsy (Kim et al., 2017b; van Sonderen et al., 2017; Binks et al., 2018; Mueller et al., 2018). So far there is no evidence, however, that the haplotypes associated with autoimmune encephalitis also increase the risk for SAD.

\section{$\underline{\text { Relevance and implications }}$}

\section{Diagnostic approach to seizures}

Individuals with a seizure disorder and comorbid SAD should be evaluated in the usual manner, (Thijs et al., 2019) with the following additional considerations tailored to specific SADs. In all cases reversible symptomatic causes such as electrolyte disturbance (e.g. IBD or SLE with renal involvement), hypoglycaemia (e.g. T1DM) or posterior reversible encephalopathy syndrome (PRES) (e.g. due to renal disease or immunosuppressive medications) should be evaluated. Encephalopathy and infectious symptoms, such as fever and meningism, should trigger rapid investigations to rule out opportunistic CNS infections. Immunosuppressed people may not exhibit a typical infectious response, such that isolated encephalopathy may be sufficient to warrant a lumbar puncture even in the absence of fever, after a space-occupying lesion has been ruled out through urgent imaging (Sonneville et al., 2017). In the setting of IBD, SLE, or antiphospholipid antibody syndrome, cerebral venous and arterial thromboembolism 
should be ruled out, especially in the setting of focal neurological symptoms and sudden headache.

Identification of a vascular lesion on MRI may trigger tailored investigations for modifiable vascular risk factors. For example, post-stroke epilepsy in an individual with SLE should prompt investigations for underlying antiphospholipid syndrome, including lupus anticoagulant, anticardiolipin, and beta- 2 glycoprotein 1 antibodies, to initiate appropriate secondary stroke prevention (Lisnevskaia et al., 2014). The diagnosis of antiphospholipid antibody syndrome rests on a combination of clinical features and supportive antibody results, reviewed elsewhere (Miyakis et al., 2006). In people with T1DM and epilepsy, timely glucose measurements in association with seizure-like events are important to determine whether seizures in them are related to hypoglycaemia, as these events are clinically indistinguishable from unprovoked epileptic seizures (Frier, 2014).

In those with SAD and focal epilepsy of unknown cause, we also recommend considering an underlying autoimmune cause, although more clinical data are needed (Quek et al., 2012). Features of autoimmune encephalitis include cognitive dysfunction, psychiatric symptoms and MRI features of encephalitis (Graus et al., 2016). Epilepsy characteristics such as frequent seizures (Gillinder et al., 2017; Vogrig et al., 2019), anti-seizure medication resistance (Dubey et al., 2017; Vogrig et al., 2019), and autonomic (Baysal-Kirac et al., 2016) or perisylvian (Gillinder et al., 2017; Steriade et al., 2018) semiology may also provide suspicion for an underlying autoimmune encephalitis, as in the individual described in box 2. Some features may suggest a specific cause, such as faciobrachial dystonic seizures presenting as an early sign of LGI1 encephalitis (Thompson et al., 2018). When such clues are present, antibody tests should be considered. The type and the extent of the tests should depend on the clinical presentation. In 
the context of chronic focal epilepsy, GAD65, LGI1, and contactin-associated protein-like 2 are the most frequently associated antibodies, whereas status epilepticus is associated with NMDAR, GABA-B, and GABA-A (Bien and Holtkamp, 2017; Dalmau and Graus, 2018; Vogrig et al., 2019). The sensitivity of serum versus CSF varies across antibodies. For example, NMDAreceptor encephalitis can be seronegative but CSF positive in $17 \%$ of cases (Titulaer et al., 2013a), while serum is more sensitive than CSF in the detection of LGI1 autoantibodies (Gadoth et al., 2017). If antibody tests through clinical laboratories are inconclusive, searching for uncharacterized antibodies (Graus et al., 2016) through research laboratories, and use of FDGpositron emission tomography (PET) (Baumgartner et al., 2013) may be worthwhile in individuals with a clinical profile highly consistent with autoimmune encephalitis.

\section{Screening for SAD}

We suggest considering screening for coeliac disease in those with gastrointestinal symptoms and focal epilepsy of unknown cause. Amongst available celiac disease antibodies, transglutaminase antibodies are most sensitive (Lebwohl et al., 2018). If transglutaminase antibodies are weakly positive, follow up testing with endomysial antibodies should be performed as they carry higher specificity (Lebwohl et al., 2018). People with positive antibodies should be referred onto a gastroenterologist for further diagnostic workup and management, as a coeliac disease diagnosis can be made without biopsy if strict clinical (i.e. gastrointestinal symptoms) and serological criteria (i.e. positive transglutaminase antibodies) are met (Lebwohl et al., 2018). Undiagnosed coeliac disease has not been associated with increased morbidity or mortality (Lebwohl et al., 2018), such that false positive antibodies leading to unnecessary biopsies in asymptomatic individuals carries little potential benefit. For those without gastrointestinal symptoms, the evidence is still too weak to support coeliac screening. We 
believe that screening of people with epilepsy without gastrointestinal symptoms should be considered in those presenting with epilepsy syndromes with a strong association with coeliac disease, which are occipital calcifications (Arroyo et al., 2002; Gobbi, 2005) or childhood occipital lobe epilepsy of unknown origin (Labate et al., 2001; Dai et al., 2014).

\section{Treatment}

Considerations in managing treatment of comorbid SAD and epilepsy include: 1) interactions between immunosuppressants and anti-seizure medications, and 2) potential benefits or risks of immunosuppressants on epilepsy and of epilepsy treatment on SADs.

\section{Drug-drug interactions}

Enzyme inducing antiseizure medications (e.g. phenytoin, carbamazepine) can reduce the levels of calcineurin inhibitors (e.g. cyclosporine, tacrolimus) and have a bidirectional relationship with glucocorticoids, with mutual induction of metabolism (Asconape, 2018). Valproate may increase the levels of mycophenolate (Asconape, 2018). The high proteinbinding properties of cyclosporine can also lead to displacement of other highly protein-bound medications (e.g. valproate, phenytoin), increase in free levels, and clinical toxicity. Risks of hepatotoxicity may also be compounded when multiple medications with hepatotoxic risks are administered in conjunction (e.g. valproate and cyclosporine) (Perucca and Gilliam, 2012). Lastly, while biologics (e.g. TNF blockers) have lower rates of drug-drug interactions than the above immunosuppressive medications, there have been reports of possible effects on cytochrome P450 enzyme activity (Kenny et al., 2013). Judicious medication choice and monitoring blood levels can mitigate risks associated with drug-drug interactions.

Teratogenicity should always be considered in women of childbearing age requiring treatment with antiseizure and immunosuppressive medications, although large scale studies are 
needed to determine the teratogenic risks of immunosuppressants and their impact on the known risks of antiseizure medications. Of note, the degree of teratogenicity varies between antiseizure medications, such that the choice of medications with lower rates of teratogenicity (e.g. levetiracetam and lamotrigine (Tomson et al., 2018)) should be considered whenever possible.

\section{Effect of immune treatment on comorbidity}

Immunosuppressants may lower the risk of developing epilepsy in people with SAD. The association of hydroxychloroquine (in SLE) (Hanly et al., 2012a) and non-steroidal antiinflammatory medications (in rheumatoid arthritis) (Ong et al., 2014) with lower risks of seizures may reflect confounding with low disease severity. The association of anti-TNF agents and other biologicals with a lower risk of epilepsy among some people with SAD may pose stronger evidence for an effect of immunosuppression on epilepsy (Ong et al., 2014). The lower risk may reflect confounding by indication, since TNF agents are generally used in SADs associated with lower risks of epilepsy (e.g. IBD) (Ong et al., 2014). The lack of detailed datasets limits the conclusions that can be drawn from this administrative database study and the ability to address potential confounders (Ong et al., 2014). Specific SAD treatments may also have effects on epilepsy. For example, a gluten-free diet might lead to improvement in seizure control, as suggested by uncontrolled, unblinded studies in coeliac disease and epilepsy (Julian et al., 2018), and can lead to lowered coeliac antibodies (Lebwohl et al., 2018). A correlation between antibody levels and seizure improvement has, however, not been ascertained in those with epilepsy and coeliac disease.

Conversely, a few epilepsy treatments may hypothetically benefit people with SAD. There is some evidence to support a systemic and central anti-inflammatory effect of vagus nerve stimulation (VNS) (Meneses et al., 2016; Zila et al., 2017). Preliminary data suggested an 
improvement in the inflammatory profile and disease severity following VNS treatment in people with rheumatoid arthritis or Crohn's disease (Bonaz et al., 2017).

\section{Immunosuppression in acute symptomatic seizures secondary to autoimmune encephalitis}

While evidence is lacking on treatment of epilepsy in the setting of SAD as a whole, immunosuppressants are often effective in controlling seizures in people with seizures and antineuronal antibodies (Thompson et al., 2018; de Bruijn et al., 2019b; Vogrig et al., 2019). Immunosuppressants are generally initiated with one of the following first-line agents: glucocorticoids, intravenous immunoglobulins and plasmapheresis (Bien and Holtkamp, 2017; Vogrig et al., 2019). If a response is seen or if a relapse occurs after withdrawal of first line immunotherapy, maintenance immunosuppression with mycophenolate mofetil or azathioprine may be initiated (Bhatia and Schmitt, 2018). In cases of seizures with definite autoimmune encephalitis without response to first line immunotherapy, second line immunotherapy with rituximab or cyclophosphamide should be considered, in view of the improved outcomes noted in anti-NMDA-receptor encephalitis (Titulaer et al., 2013a), and autoimmune limbic encephalitis with and without antibodies (Lee et al., 2016). The immune therapies outlined above are based on observational data, to the exception of one positive randomized controlled trial demonstrating the effect of IVIg in LGI1 and CASPR2 mediated seizures (Dubey et al., 2020).

A delay to initiation of immunosuppressive treatment worsens seizure and cognitive outcomes in the setting of LGI1 antibody associated faciobrachial dystonic seizures (Thompson et al., 2018) and anti-NMDA receptor encephalitis (Titulaer et al., 2013b; Balu et al., 2019). A robust response to steroids may support the diagnosis of SREAT (Laurent et al., 2016). Similarly, the use of immunosuppressive drug trials can be used to support an autoimmune cause 
of seizures when suspected clinically, although objective outcome measures should be utilized to minimize bias (Toledano et al., 2014). Other immunomodulatory treatments targeting innate immunity may also have a role in the treatment of certain specific epilepsies. The use of IL-1 $\beta$ blockade has also anecdotally been effective in individuals with febrile-infectious related epilepsy syndrome (Kenney-Jung et al., 2016; Dilena et al., 2019; Sa et al., 2019), and in drugrefractory epilepsies associated with inflammatory conditions (DeSena et al., 2018) while TNF or IL-6 blockers benefitted a subset of people with RE in an open label pilot study (Lagarde et al., 2016) or people with new onset refractory status epilepticus (Jun et al., 2018; CantarínExtremera et al., 2020), respectively. Anti-inflammatory drugs targeting IL-1 $\beta$, TNF or IL-6 could be investigated as agents potentially targeting immune mediators of epilepsy in people with comorbid SADs.

\section{Toxicity of SAD and epilepsy therapies}

Neurotoxic effects of immunosuppressants are rare - for example, the incidence of PRES in people post transplantation receiving calcineurin inhbitors is estimated to be $0.49 \%$ (Bartynski et al., 2008; Chen et al., 2016). Evaluation for PRES with neuroimaging should considered in people with SADs developing seizures in the setting of calcineurin inhibitors (Chen et al., 2016). Conversely, the risk of idiosyncratic side effects from anti-seizure medications may be heightened in people with SADs. For example, the risk of aplastic anaemia with felbamate use increases with a history of SAD (Perucca and Gilliam, 2012). Among people with LGI1 antibody mediated encephalitis, the use of aromatic antiseizure medication has been associated with relatively higher effectivity, but also higher rates of cutaneous drug reactions in multi-ethnic populations (Thompson et al., 2018; de Bruijn et al., 2019b). Lastly, carbamazepine, phenytoin, and phenobarbital are rarely associated with the development of clinical and serological lupus, 
and subsequent resolution upon discontinuation of the drug (Perucca and Gilliam, 2012; AlvarezLario et al., 2019). Individuals with SAD may also be at higher risk of adverse bone health outcomes with enzyme-inducing antiseizure medications, due to concurrent treatment with glucocorticoids (Frenkel et al., 2015). Glucocorticoids may also increase psychiatric comorbidities, which are common in people with epilepsy (Jette et al., 2017).

\section{Conclusions and future directions}

Seizures and epilepsy occur more frequently in people with SAD than in the general population (Ong et al., 2014). The risk of epilepsy seems elevated across the spectrum of SADs but is highest in those with systemic lupus erythematosus and type 1 diabetes mellitus (Ong et al., 2014). The relationship between epilepsy and SAD is complex and probably multifactorial. The occurrence of acute symptomatic seizures complicates this association and may occur due to neurotoxic effects of immunosuppressants (Chen et al., 2016), acute vascular insults associated with an SAD (Kohoutova et al., 2015; Fleetwood et al., 2018), or metabolic abnormalities (Frier, 2014; Mastrangelo et al., 2019). Seizures may result from structural brain injury due to metabolic (ketoacidosis or recurrent hypoglycaemia in T1DM) (Mastrangelo et al., 2019) or vascular mediators (e.g. stroke in IBD, SLE, T1DM, rheumatoid arthritis), or inflammatory mechanisms (de Ferranti et al., 2014; Chang et al., 2015; Kohoutova et al., 2015; Fleetwood et al., 2018; Vezzani et al., 2019). Shared genetic risk factors may confound the association between SAD and epilepsy (ILAE Consortium on Complex Epilepsies, 2018) but are still largely unknown. In the absence of vascular, toxic, genetic and metabolic mediators of seizures, central effects of systemic immunological dysfunction may play a role. Neuroinflammation is a hallmark of epileptogenesis and may be triggered not only by neuronal injury but also by 
systemic immune activation (box 1). There is experimental evidence of systemic immune activation precipitating neuroinflammation and seizures (Vezzani et al., 2019), but there is still too little human evidence for direct immunological dysfunction resulting in seizures among people with SADs. The role of antineuronal antibodies in the mediation of epilepsy in those with SADs is understudied (Quek et al., 2012). Investigation and management of vascular, metabolic, and toxic causes of seizures in people with epilepsy and SAD should however be complemented by autoimmune investigations in those with a clinical profile consistent with autoimmune encephalitis (Box 2) (Graus et al., 2016). Lastly, epilepsy and SAD treatment may bring specific risks related to medication interactions and disease modification. Conversely, immunosuppressive medications can improve seizure control in the setting of autoimmune encephalitis (Bien and Holtkamp, 2017; Vogrig et al., 2019) and steroid-responsive encephalopathy with associated thyroiditis (Laurent et al., 2016).

Our review only focused on those SADs with sufficient reports to support an linkage between SADs and epilepsy. Future administrative database studies are needed to clarify whether the association between epilepsy and SAD is found across the full spectrum of SADs including skin autoimmune conditions and neuromuscular conditions that do not directly affect the brain. While administrative studies have been instrumental in demonstrating various associations between epilepsy and SADs, they carry the risk for artifactual comorbidity, classification errors (distinction between acute symptomatic seizures vs. chronic epilepsy) and fail to provide detailed clinical risk profiles (Keezer et al., 2016a). Administrative studies should therefore be complemented by clinical cohort studies to specify which characteristics of people with SAD bring a high susceptibility to seizures and to address the epilepsy characteristics. Conversely, the role of screening for occult SAD, particularly coeliac disease in people with epilepsy, should be 
clarified. Large, longitudinal cohort studies are needed to determine whether epilepsy or autoimmune disorders arise first. Clinical studies are critically needed to define risk profiles and screening strategies but also to explore the mechanisms of the association between SAD and epilepsy, by assessing immunologic mediators including cytokines and antineuronal antibodies. These studies should also pay special attention to the specific possible mediators for each SAD. Unravelling the complex association between SAD and epilepsy may have potentially important treatment implications as this could support the investigation of targeted treatments (e.g. immunosuppressants, ketogenic diet to alter the gut microbiome (Olson et al., 2018)). A better understanding of the mechanisms underlying the co-existence of epilepsy and individual SADs is a critical next step to guide new antiseizure and anti-epileptogenic treatments.

\section{Contributors}

RDT and JWS conceptualised the review which was then designed by CS and RDT. CS carried out searches and drafted the section on non-immune mediators, gastrointestinal and rheumatologic disorders as well as the "Relevance and implications" section. MT drafted the "Immune mediators" section. AV drafted the "Preclinical findings linking neuroinflammation, seizures and epileptogenesis" section. JWS drafted the introduction. RDT drafted the endocrinological disorders section and the conclusion and future directions section. The table was done by CS and RDT. All authors edited and approved the manuscript.

\section{Acknowledgements}

The authors are grateful to Dr GS Bell for critically reviewing the manuscript. CS receives funding from the Finding A Cure for Epilepsy and Seizures (FACES) foundation and the American Epilepsy Society. JWS is based at NIHR University College London Hospitals 
Biomedical Research Centre, which receives a proportion of funding from the UK Department of Health's Comprehensive Research Centres funding scheme. He receives research support from the Marvin Weil Epilepsy Research Fund, the UK Epilepsy Society, and the Christelijke Vereniging voor de Verpleging van Lijders aan Epilepsie, The Netherlands. RDT receives research support from the Dutch National Epilepsy Fund (NEF, project 15-10), The Netherlands Organisation for Health Research and Development (ZonMW), NUTS Ohra Fund, Medtronic, Christelijke Vereniging voor de Verpleging van Lijders aan Epilepsie, The Netherlands and AC Thomson Foundation. AV was supported by European Union's Seventh Framework Programme (FP7/2007-2013) under grant agreement n. 602102 (EPITARGET).

\section{Competing interests}

CS receives research support and fees as consultant from UCB. MT and RDT receive funding from the Dutch National Epilepsy Fund (NEF, project 14-19). MT receives funding from the Netherlands Organisation for Health Research and Development (ZonMW, Memorabel program). MT has received fees as speaker or consultant from MedImmune LLC, Guidepoint Consultancy, and Novartis. MT has a patent on methods for typing neurological disorders and cancer, and devices for use therein to Erasmus University Medical Center. JWS has been consulted by and received research grants and fees for lectures from UCB Pharma, GW Pharma and Zogenix. AV has nothing to disclose. RDT has received funding from Medtronic, fees as a consultant from Theraverance and fees for lectures from Medtronic, UCB, Novartis and GSK. 
Steriade et al. 2020 Systemic autoimmune disorders and epilepsy 


\section{Box 1: Preclinical findings linking neuroinflammation, seizures and epileptogenesis}

Neuroinflammation can precede and follow seizures, and accompany systemic immune activation. Animal models of acquired epilepsy or some genetic forms (absence and progressive myoclonus epilepsies) and clinical evidence suggest that an inflammatory brain response precedes epilepsy onset, and persists with seizure recurrence (Vezzani et al., 2019). Neuroinflammation may result from the brain's innate immune response to the insults that can cause epilepsy. Recurrent seizures and status epilepticus in animals without pre-existing brain pathology may also induce a lasting neuroinflammatory response, which, in turn, promotes further seizures (Vezzani et al., 2019). Lastly, neuroinflammation may also be a secondary brain response to a primary systemic immune activation of leukocytes, typical of SADs (Vezzani et al., 2019). In the setting of systemic immune activation, neuroinflammation may be initiated by several mechanisms: the release of inflammatory mediators by activated cellular components of the $\mathrm{BBB}$, the infiltration of circulating cytokines or immune cells into the brain parenchyma, and the dysregulation of the hypothalamicpituitary-adrenal axis (O'Toole et al., 2014). Once initiated, the neuroinflammatory response leads to the release of an array of inflammatory mediators and may lead to brain extravasation of leukocytes. The neuroinflammatory pathways contributing to epileptogenesis involve rapid and long-term neurophysiological changes chiefly mediated by cytokines, chemokines, prostaglandins and DAMPs. The rapid effects cause post-translational changes in neurons, such as phosphorylation of ion channel subunits by activation of protein kinases (Roseti et al., 2015). The long-term effects involve gene transcription and structural changes resulting in aberrant excitatory synaptogenesis (Kim et al., 2017a). Lastly, BBB dysfunction is reciprocally associated with neuroinflammation (Vezzani et al., 2019). BBB dysfunction facilitates the brain extravasation of serum albumin, peripheral immune cells and inflammatory molecules, promoting neuronal 
Steriade et al. 2020 Systemic autoimmune disorders and epilepsy

network excitability and the propensity to generate seizures (Vezzani et al., 2019). The neurophysiological effects of neuroinflammation in epilepsy have not been assessed in preclinical SAD models. Figure 1A summarizes the role of neuroinflammation in epileptogenesis. 


\section{Box 2: Case study: New onset focal epilepsy in a female with a systemic autoimmune disorder}

A woman aged 62 presented with new onset epilepsy. She had a personal and family history of autoimmune thyroiditis and a family history of juvenile rheumatoid arthritis. She presented to a local casualty with two focal to bilateral tonic-clonic seizures. An EEG showed left frontotemporal interictal epileptiform discharges and an MRI was unremarkable. Levetiracetam was initiated. She then started to have daily events consisting of sudden anxiety, rising abdominal sensation followed by laryngeal constriction, consistent with focal aware seizures with temporo-perisylvian semiology. Escalation in levetiracetam dose did not reduce seizure frequency. She also started forgetting recent events and had to set reminders for tasks. Cognitive symptoms had been ascribed to medication side effects. Neurological examination two months after the onset of epilepsy revealed impairment of episodic memory, with an inability to recall four out of five words despite cueing. There were no psychiatric symptoms or personality changes. Given the absence of a cause on MRI, the high seizure frequency despite antiseizure medication, perisylvian semiology, associated cognitive dysfunction, and comorbid SAD, she underwent evaluation for underlying autoimmune encephalitis. Serum testing for antineuronal antibodies revealed positive LGI1 autoantibodies. Cerebrospinal fluid evaluation did not show any abnormalities in cell count, protein or oligoclonal banding, and failed to reveal LGI1 autoantibodies. An underlying malignancy such as thymoma was ruled out by computed tomography (CT) of the chest, abdomen and pelvis. A diagnosis of anti-LGI1 encephalitis was made. She underwent treatment with steroids, in the form of a pulse of intravenous methylprednisolone, followed by high dose oral corticosteroids, with resolution of seizures and improvement in cognitive status. 


\section{Box 3: Key points}

1. Seizures and epilepsy occur more frequently in people with systemic autoimmune disorders (SADs) than in the general population.

2. Immune dysfunction may mediate the relationship between SADs and epilepsy. In addition, cerebrovascular disease, genetic, metabolic, and gastrointestinal mediators may play a role.

3. Careful evaluation for infectious, vascular and metabolic causes of acute symptomatic seizures should be performed when a subject with SAD presenting with new onset seizures.

4. People with SADs may have a higher risk of autoimmune encephalitis, for which a diagnostic evaluation should be undertaken in the presence of other suggestive clinical features.

5. Immunosuppressive medications can improve seizure control in the setting of autoimmune encephalitis and steroid-responsive encephalopathy with associated thyroiditis. 


\section{Figure Legends}

Figure 1. Peripheral and central nervous system instigation of neuroinflammation and its role in seizures and epileptogenesis, in the context of innate immunity (A) and cellular immunity (B).

A. The neuroinflammatory response can be initiated by peripheral immune activation and central nervous system (CNS) injury. Peripheral immune dysfunction leads to activated leukocytes and an increase in cytokine production, which may cross a dysfunctional blood-brain-barrier (BBB), which may itself promote neuroinflammation. A dysfunctional hypothalamic-pituitary-adrenal (HPA) axis may also mediate a neuroinflammatory response to peripheral inflammation. Neuronal injury itself may lead to an innate immune response, mediated by pattern recognition receptors (PRRs) and damage-associated molecular patterns (DAMPs), which in turn initiates a neuroinflammatory response through activated microglia and astrocytes. Inflammatory mediators may effect increased neuronal excitability and seizures through rapid onset channelopathic effects, and long term transcriptional changes. Seizures themselves promote further neuroinflammation.

B. Specific neurologic syndromes associated with cellular immunity may also manifest with seizures, often alongside cognitive and psychiatric changes. These syndromes can be associated with antibodies target intracellular antigens (bystanders of a predominantly cytotoxic $\mathrm{T}$ cell driven response), or antibodies to extracellular synaptic or membrane antigens (which directly lead to a predominantly B cell driven immune disease).

Abbreviations: BBB - blood brain barrier, DAMPs - damage-associated molecular patterns, HPA - hypothalamic-pituitary-adrenal axis, PRRs - pattern recognition receptors. 
Table 1. Rheumatological autoimmune disorders and epilepsy epidemiological studies

\begin{tabular}{|c|c|c|c|c|c|c|c|c|c|}
\hline Cohort type & Study design & $\begin{array}{l}\text { Sample } \\
\text { size }\end{array}$ & $\begin{array}{l}\text { Adult vs } \\
\text { paediatric }\end{array}$ & $\begin{array}{l}\text { Selection } \\
\text { method }\end{array}$ & $\begin{array}{l}\text { Diagnosis } \\
\text { ascertainment } \\
\text { (epilepsy) }\end{array}$ & $\begin{array}{l}\text { Diagnosis } \\
\text { ascertainment } \\
\text { (SAD) }\end{array}$ & Control group & $\begin{array}{l}\text { Prevalence, } \\
\text { incidence, odds } \\
\text { ratio }(\mathrm{OR}), \text { and/or } \\
\text { hazard ratio }(\mathrm{HR})\end{array}$ & Notes \\
\hline \multicolumn{10}{|c|}{ Rheumatoid arthritis (RA) } \\
\hline $\begin{array}{l}\text { Clinical } \\
\text { cohorts }\end{array}$ & $\begin{array}{l}\text { Case series (Hanly et al., } \\
\text { 2012b) }\end{array}$ & 53 cases & Adult & Clinic registry & Registry data & $\begin{array}{l}\text { Diagnostic } \\
\text { criteria }\end{array}$ & None & $0 \%$ & \\
\hline $\begin{array}{l}\text { Administrative } \\
\text { databases }\end{array}$ & $\begin{array}{l}\text { Nested case control (Ong } \\
\text { et al., 2014), retrospective } \\
\text { cohort (Chang } \text { et al., 2015) }\end{array}$ & $\begin{array}{l}22,980- \\
32,005 \\
\text { cases, total } \\
\text { cohort } \\
2,518,034\end{array}$ & $\begin{array}{l}\text { Adult and } \\
\text { paediatric }\end{array}$ & $\begin{array}{l}\text { Nationwide } \\
\text { health insurance } \\
\text { claims }\end{array}$ & $\begin{array}{l}\text { ICD code and/or } \\
\text { prescription of at } \\
\text { least } 1 \text { AED }\end{array}$ & ICD code & $\begin{array}{l}\text { Subjects without } \\
\text { RA within cohort } \\
\text { Age, sex, year of } \\
\text { RA diagnosis } \\
\text { matched }\end{array}$ & $\begin{array}{l}\text { OR } 3 \cdot 5 \\
1 \cdot 14 \text { (cases) vs } \\
0 \cdot 90 \text { (controls) per } \\
1,000 \text { person years. } \\
\text { HR } 1 \cdot 2\end{array}$ & \\
\hline \multicolumn{10}{|c|}{ Systemic lupus erythrematosus (SLE) } \\
\hline $\begin{array}{l}\text { Clinical } \\
\text { cohorts }\end{array}$ & $\begin{array}{l}\text { Case series(Herranz et al., } \\
\text { 1994; Sanna et al., 2003; } \\
\text { Appenzeller } \text { et al., 2004; } \\
\text { Hanly et al., 2005; } \\
\text { Mikdashi } \text { et al., 2005; } \\
\text { Andrade } \text { et al., 2008; } \\
\text { Gonzalez-Duarte } \text { et al., } \\
\text { 2008; Ramsey-Goldman et } \\
\text { al., 2008; Harboe } \text { et al., } \\
\text { 2009; Hanly et al., 2012b; } \\
\text { Steup-Beekman } \text { et al., } \\
\text { 2013) }\end{array}$ & $\begin{array}{l}53-1631 \\
\text { cases }\end{array}$ & $\begin{array}{l}\text { Adult and } \\
\text { paediatric }\end{array}$ & $\begin{array}{l}\text { Hospital or clinic } \\
\text { database, } \\
\text { multicentre } \\
\text { registry }\end{array}$ & $\begin{array}{l}\text { Chart review, } \\
\text { questionnaire or } \\
\text { interview, registry } \\
\text { data }\end{array}$ & $\begin{array}{l}\text { ACR diagnostic } \\
\text { criteria }\end{array}$ & None & $\begin{array}{l}2 \cdot 3-9 \cdot 5 \% \\
(28 \% \text { outlier } \\
\text { (Steup-Beekman } \text { et } \\
\text { al., 2013)) }\end{array}$ & $\begin{array}{l}\text { Little data on single vs } \\
\text { recurrent seizures. } \\
\text { Majority of seizures after } \\
\text { onset of SLE. Lower } \\
\text { prevalence in study } \\
\text { excluding structural or } \\
\text { metabolic causes } \\
\text { (Appenzeller } \text { et al., 2004). }\end{array}$ \\
\hline $\begin{array}{l}\text { Administrative } \\
\text { databases }\end{array}$ & $\begin{array}{l}\text { Case control (Watad et al., } \\
\text { 2018), nested case-control } \\
\text { (Ong et al., 2014), and } \\
\text { retrospective cohort (Tsai, } \\
\text { 2014) }\end{array}$ & $\begin{array}{l}5,018- \\
32,301 \\
\text { cases, } \\
25,090- \\
129,204 \\
\text { controls }\end{array}$ & Adult & $\begin{array}{l}\text { National } \\
\text { database } \\
\text { Insurance claims }\end{array}$ & $\begin{array}{l}\text { ICD code and/or } \\
\text { prescription of at } \\
\text { least } 1 \mathrm{AED}\end{array}$ & ICD code & $\begin{array}{l}\text { Age and gender } \\
\text { matched controls } \\
\text { People without } \\
\text { SLE within cohort }\end{array}$ & $\begin{array}{l}4 \% \text { (cases) vs } 0.9 \% \\
\text { (controls) } \\
\text { OR } 7 \cdot 4 \\
9 \cdot 1 \text { (cases) vs } 3 \cdot 18 \\
\text { (controls) per } \\
10,000 \text { person years } \\
\text { HR } 2 \cdot 33\end{array}$ & $\begin{array}{l}\text { Antiphospholipid } \\
\text { syndrome: OR 9.0 (7.7- } \\
10 \cdot 5)\end{array}$ \\
\hline \multicolumn{10}{|c|}{ Sjogren's syndrome } \\
\hline $\begin{array}{l}\text { Clinical } \\
\text { cohorts }\end{array}$ & $\begin{array}{l}\text { Case series (Harboe et al., } \\
\text { 2009; Moreira et al., 2014) }\end{array}$ & $\begin{array}{l}72-93 \\
\text { cases }\end{array}$ & Adult & Hospital or clinic & Chart review & $\begin{array}{l}\text { Diagnostic } \\
\text { criteria }\end{array}$ & None & $2 \cdot 2-3 \%$ & $\begin{array}{l}\text { Multiple subcortical } \\
\text { lesions on MRI in both } \\
\text { individuals who } \\
\text { developed seizures in a } \\
\text { cohort of } 93 \text { subjects, } \\
\text { prior to onset of sicca } \\
\text { (Moreira } \text { et al., 2014) }\end{array}$ \\
\hline $\begin{array}{l}\text { Administrative } \\
\text { databases }\end{array}$ & $\begin{array}{l}\text { Nested case control (Ong } \\
\text { et al., 2014) }\end{array}$ & $\begin{array}{l}3614 \text { cases, } \\
\text { total cohort } \\
2,518,034\end{array}$ & $\begin{array}{l}\text { Adult and } \\
\text { paediatric }\end{array}$ & $\begin{array}{l}\text { Nationwide } \\
\text { health insurance } \\
\text { claims }\end{array}$ & $\begin{array}{l}\text { ICD code and } \\
\text { prescription of at } \\
\text { least } 1 \mathrm{AED}\end{array}$ & Not stated & $\begin{array}{l}\text { Individuals without } \\
\text { Sjogren's within } \\
\text { cohort }\end{array}$ & OR $4 \cdot 5$ & \\
\hline
\end{tabular}


Steriade et al. 2020 Systemic autoimmune disorders and epilepsy

\begin{tabular}{|c|c|c|c|c|c|c|c|c|c|}
\hline $\begin{array}{l}\text { Clinical } \\
\text { cohorts }\end{array}$ & $\begin{array}{l}\text { Case series (Dutra et al., } \\
\text { 2011; Kutlu et al., 2015) }\end{array}$ & $\begin{array}{l}42-223 \\
\text { cases }\end{array}$ & $\begin{array}{l}\text { Adult and } \\
\text { paediatric }\end{array}$ & Clinic & Chart review & $\begin{array}{l}\text { Diagnostic } \\
\text { criteria }\end{array}$ & None & $3 \cdot 9-16 \cdot 7 \%$ & $\begin{array}{l}\text { Higher prevalence in } \\
\text { people with neuro- } \\
\text { Behcet's only. }\end{array}$ \\
\hline
\end{tabular}


Table 2. Endocrinological autoimmune disorders and epilepsy epidemiological studies

\begin{tabular}{|c|c|c|c|c|c|c|c|c|c|}
\hline Cohort type & Study design & $\begin{array}{l}\text { Sample } \\
\text { size }\end{array}$ & $\begin{array}{l}\text { Adult vs } \\
\text { paediatric }\end{array}$ & $\begin{array}{l}\text { Selection } \\
\text { method }\end{array}$ & $\begin{array}{l}\text { Diagnosis } \\
\text { ascertainment } \\
\text { (epilepsy) }\end{array}$ & $\begin{array}{l}\text { Diagnosis } \\
\text { ascertainment } \\
\text { (SAD) }\end{array}$ & Control group & $\begin{array}{l}\text { Prevalence, } \\
\text { incidence, odds } \\
\text { ratio }(\text { OR), } \\
\text { and/or hazard } \\
\text { ratio }(\text { HR })\end{array}$ & Notes \\
\hline \multicolumn{10}{|c|}{ Type 1 diabetes mellitus } \\
\hline $\begin{array}{l}\text { Clinical } \\
\text { cohorts }\end{array}$ & $\begin{array}{l}\text { Case series (Keezer } \text { et al., } \\
\text { 2015), case } \\
\text { control,(McCorry et al., } \\
\text { 2006) and uncontrolled } \\
\text { retrospective cohort } \\
\text { (O'Connell et al., 2008; } \\
\text { Ramakrishnan and } \\
\text { Appleton, 2012; Schober } \\
\text { et al., 2012) }\end{array}$ & $\begin{array}{l}245- \\
45,851 \\
\text { cases, } \\
150,000 \\
\text { controls }\end{array}$ & $\begin{array}{l}\text { Adult or } \\
\text { paediatric }\end{array}$ & $\begin{array}{l}\text { Clinic, } \\
\text { Multicentre } \\
\text { database }\end{array}$ & $\begin{array}{l}\text { Chart review } \\
\text { Pre-defined } \\
\text { epilepsy per ILAE } \\
\text { criteria or } \\
\text { treatment with } 1 \\
\text { AED }\end{array}$ & $\begin{array}{l}\text { Not stated, self- } \\
\text { reported } \\
\text { diagnosis of } \\
\text { hospital records } \\
\text { and insulin } \\
\text { treatment }\end{array}$ & $\begin{array}{l}\text { Population based } \\
\text { prevalence }\end{array}$ & $\begin{array}{l}0.99 \% \\
\text { OR } 4 \cdot 4 \\
8 \cdot 7-21 \text { per } 1,000 \\
\text { person years }\end{array}$ & $\begin{array}{l}\text { Active epilepsy vs lifetime } \\
\text { diagnosis accounting for } \\
\text { some of the variability. }\end{array}$ \\
\hline $\begin{array}{l}\text { Administrative } \\
\text { databases }\end{array}$ & $\begin{array}{l}\text { Nested case-control (Ong } \\
\text { et al., 2014), retrospective } \\
\text { cohort (Fazeli Farsani et } \\
\text { al., 2015; Chou } \text { et al., } \\
\text { 2016; Dafoulas } \text { et al., } \\
\text { 2017) }\end{array}$ & $\begin{array}{l}915- \\
43,704 \\
\text { cases, } \\
\text { total } \\
\text { cohort } \\
2,518,034\end{array}$ & $\begin{array}{l}\text { Adult and } \\
\text { paediatric }\end{array}$ & $\begin{array}{l}\text { Nationwide } \\
\text { health insurance } \\
\text { claims, pharmacy } \\
\text { data, primary } \\
\text { care clinics }\end{array}$ & $\begin{array}{l}\text { ICD code and/or } \\
\text { prescription of at } \\
\text { least } 1-2 \text { or more } \\
\text { AEDs }\end{array}$ & $\begin{array}{l}\text { ICD code or } \\
\text { insulin } \\
\text { prescription }\end{array}$ & $\begin{array}{l}\text { Subjects without } \\
\text { T1DM within } \\
\text { cohort } \\
\text { Age, gender and } \\
\text { county matched } \\
\text { subjects }\end{array}$ & $\begin{array}{l}\text { OR } 5 \cdot 2 \\
30-132 \text { (cases) vs } \\
10 \cdot 4-44 \text { (controls) } \\
\text { per } 10,000 \text { person } \\
\text { years } \\
\text { HR } 2 \cdot 0-3 \cdot 01\end{array}$ & $\begin{array}{l}\text { Higher risk of subsequent } \\
\text { epilepsy in individuals with } \\
\text { hypoglycaemic episodes. } \\
\text { Higher epilepsy incidence } \\
\text { in study without clearly } \\
\text { stated criteria for epilepsy } \\
\text { diagnosis (Dafoulas } \text { et al., } \\
\text { 2017). }\end{array}$ \\
\hline \multicolumn{10}{|c|}{ Hashimoto's thyroiditis } \\
\hline $\begin{array}{l}\text { Administrative } \\
\text { databases }\end{array}$ & $\begin{array}{l}\text { Nested case control (Ong } \\
\text { et al., 2014) }\end{array}$ & $\begin{array}{l}9830 \\
\text { cases, } \\
\text { total } \\
\text { cohort } \\
2,518,034 \\
\end{array}$ & $\begin{array}{l}\text { Adult and } \\
\text { paediatric }\end{array}$ & $\begin{array}{l}\text { Nationwide } \\
\text { health insurance } \\
\text { claims }\end{array}$ & $\begin{array}{l}\text { ICD code and } \\
\text { prescription of at } \\
\text { least } 1 \text { AED }\end{array}$ & $\begin{array}{l}\text { ICD code (Ong } \\
\text { et al., 2014) }\end{array}$ & $\begin{array}{l}\text { Subjects without } \\
\text { Hashimoto's } \\
\text { within cohort }\end{array}$ & OR $2 \cdot 4$ & \\
\hline
\end{tabular}


Table 3. Gastrointestinal autoimmune disorders and epilepsy epidemiological studies

\begin{tabular}{|c|c|c|c|c|c|c|c|c|c|}
\hline Cohort type & Study design & $\begin{array}{l}\text { Sample } \\
\text { size }\end{array}$ & $\begin{array}{l}\text { Adult vs } \\
\text { paediatric }\end{array}$ & $\begin{array}{l}\text { Selection } \\
\text { method }\end{array}$ & $\begin{array}{l}\text { Diagnosis } \\
\text { ascertainment } \\
\text { (epilepsy) }\end{array}$ & $\begin{array}{l}\text { Diagnosis } \\
\text { ascertainment } \\
\text { (SAD) }\end{array}$ & Control group & $\begin{array}{l}\text { Prevalence, } \\
\text { incidence, odds } \\
\text { ratio }(\mathrm{OR}), \text { and/or } \\
\text { hazard ratio (HR) }\end{array}$ & Notes \\
\hline \multicolumn{10}{|l|}{ Coeliac disease } \\
\hline $\begin{array}{l}\text { Clinical } \\
\text { cohorts }\end{array}$ & $\begin{array}{l}\text { Case series (Hanly et al., } \\
\text { 1982; Kieslich et al., 2001; } \\
\text { Labate } \text { et al., 2001; } \\
\text { Pengiran Tengah et al., } \\
\text { 2004; Vaknin } \text { et al., 2004; } \\
\text { Bürk et al., 2009) case- } \\
\text { control (Chapman, 1978; } \\
\text { Cronin } \text { et al., 1998; } \\
\text { Luostarinen } \text { et al., 2001; } \\
\text { Zelnik et al., 2004; Ranua } \\
\text { et al., 2005; Dalgic } \text { et al., } \\
\text { 2006; Mavroudi } \text { et al., } \\
\text { 2007; Ruggieri } \text { et al., } \\
\text { 2008; Giordano } \text { et al., } \\
\text { 2009; Peltola et al., 2009; } \\
\text { Dai } \text { et al., 2014) }\end{array}$ & $\begin{array}{l}48-968 \\
\text { cases } \\
34-584 \\
\text { controls }\end{array}$ & $\begin{array}{l}\text { Adult, } \\
\text { paediatric or } \\
\text { both }\end{array}$ & $\begin{array}{l}\text { Clinic, local } \\
\text { registry, } \\
\text { advertisement }\end{array}$ & $\begin{array}{l}\text { Chart review or } \\
\text { questionnaire }\end{array}$ & $\begin{array}{l}\text { Biopsy with or } \\
\text { without response } \\
\text { to diet } \\
\text { Antibodies alone }\end{array}$ & $\begin{array}{l}\text { Pregnant women, } \\
\text { historical } \\
\text { controls age, } \\
\text { gender and } \\
\text { county matched } \\
\text { controls or } \\
\text { unmatched } \\
\text { healthy controls }\end{array}$ & $\begin{array}{l}1 \cdot 1-6 \cdot 3 \% \text { (cases) } \\
\text { vs } 0-1 \cdot 4 \% \\
\text { (controls) }\end{array}$ & $\begin{array}{l}\text { Outlier studies reporting } \\
\text { highest prevalence rates } \\
\text { may have suffered from } \\
\text { selection bias (Chapman, } \\
\text { 1978; Bürk } \text { et al., 2009). } \\
\text { Coeliac disease predated } \\
\text { epilepsy in } 2 / 3 \text { cases } \\
\text { (Vaknin } \text { et al., 2004). } \\
\text { Intracranial calcifications } \\
\text { not always associated with } \\
\text { a diagnosis of coeliac } \\
\text { disease (Luostarinen } \text { et al., } \\
\text { 2001) but seen in } 1 / 2 \text { of } \\
\text { cases of childhood occipital } \\
\text { epilepsy and coeliac disease } \\
\text { (Labate } \text { et al., 2001). }\end{array}$ \\
\hline $\begin{array}{l}\text { Administrative } \\
\text { databases }\end{array}$ & $\begin{array}{l}\text { Nested case-control (Ong } \\
\text { et al., 2014), retrospective } \\
\text { cohort (Ludvigsson } \text { et al., } \\
\text { 2012a) }\end{array}$ & $\begin{array}{l}1885- \\
28,885 \\
\text { cases, vs } \\
143,166- \\
2,516,149 \\
\text { controls }\end{array}$ & $\begin{array}{l}\text { Adult and } \\
\text { paediatric }\end{array}$ & $\begin{array}{l}\text { Nationwide } \\
\text { health insurance } \\
\text { claims and } \\
\text { registry }\end{array}$ & $\begin{array}{l}\text { ICD code with } \\
\text { prescription of at } \\
\text { least } 1 \mathrm{AED}\end{array}$ & $\begin{array}{l}\text { Biopsy or ICD } \\
\text { code }\end{array}$ & $\begin{array}{l}\text { People without } \\
\text { coeliac within } \\
\text { cohort } \\
\text { Age, sex, year } \\
\text { and county } \\
\text { matched without } \\
\text { biopsy }\end{array}$ & $\begin{array}{l}\text { OR } 1 \cdot 18-4 \cdot 5 \\
\text { HR } 1 \cdot 42\end{array}$ & $\begin{array}{l}\text { OR higher among children } \\
\text { (OR } 16 \cdot 7) \text { than non-elderly } \\
\text { adult (OR } 2 \cdot 5) \text {. } \\
\text { Study using ICD code for } \\
\text { diagnosis of coeliac disease } \\
\text { found higher prevalence of } \\
\text { epilepsy than study using } \\
\text { biopsy result. }\end{array}$ \\
\hline \multicolumn{10}{|c|}{ Inflammatory bowel disease } \\
\hline $\begin{array}{l}\text { Clinical } \\
\text { cohorts }\end{array}$ & $\begin{array}{l}\text { Case series (Lossos et al., } \\
\text { 1995; Elsehety and } \\
\text { Bertorini, 1997; Oliveira et } \\
\text { al., 2008; Benavente and } \\
\text { Morís, 2011) case control } \\
\text { (Ben-Or et al., 2015) }\end{array}$ & $\begin{array}{l}50-648 \\
\text { cases vs } \\
42 \\
\text { controls }\end{array}$ & $\begin{array}{l}\text { Adult and/or } \\
\text { paediatric }\end{array}$ & $\begin{array}{l}\text { Hospital } \\
\text { database }\end{array}$ & $\begin{array}{l}\text { Chart review } \\
\text { Questionnaire then } \\
\text { interview }\end{array}$ & $\begin{array}{l}\text { Pathologically } \\
\text { confirmed }\end{array}$ & $\begin{array}{l}\text { Age and gender } \\
\text { matched subjects }\end{array}$ & $0-6 \cdot 1 \%$ (cases) & $\begin{array}{l}\text { Case series, acute } \\
\text { symptomatic causes } \\
\text { excluded, did not yield any } \\
\text { cases of epilepsy (Lossos } e t \\
\text { al., 1995) }\end{array}$ \\
\hline $\begin{array}{l}\text { Administrative } \\
\text { databases }\end{array}$ & $\begin{array}{l}\text { Case control (Virta and } \\
\text { Kolho, 2013) nested case } \\
\text { control (Ong et al., 2014) }\end{array}$ & $\begin{array}{l}596- \\
19,464 \\
\text { cases, } \\
\text { total } \\
\text { cohort } \\
2,518,034 \\
\end{array}$ & $\begin{array}{l}\text { Adult and } \\
\text { paediatric }\end{array}$ & $\begin{array}{l}\text { Nationwide } \\
\text { health insurance } \\
\text { claims or } \\
\text { registry }\end{array}$ & $\begin{array}{l}\text { ICD code and } \\
\text { prescription of at } \\
\text { least } 1 \mathrm{AED}\end{array}$ & $\begin{array}{l}\text { National disability } \\
\text { records or ICD } \\
\text { code }\end{array}$ & $\begin{array}{l}\text { People without } \\
\text { IBD within } \\
\text { cohort }\end{array}$ & $\begin{array}{l}\text { Ulcerative colitis: } \\
\text { OR } 2 \cdot 5-3 \cdot 82 \\
\text { Crohn's disease: } \\
\text { OR } 2-3 \cdot 1\end{array}$ & $\begin{array}{l}\text { Prevalence of epilepsy } \\
\text { among children markedly } \\
\text { higher (OR } 8 \cdot 4 \text { for UC, } 6 \cdot 2 \\
\text { for Crohn's disease). (Ong } \\
\text { et al., 2014) }\end{array}$ \\
\hline
\end{tabular}


Steriade et al. 2020 Systemic autoimmune disorders and epilepsy 


\section{$\underline{\text { References }}$}

Alvarez-Lario B, Bartulos-Iglesias M, Colazo-Burlato M, Macarron-Vicente J. Carbamazepineinduced systemic lupus erythematosus: A case-based review. European journal of rheumatology 2019; 6(1): 48-54.

Amanat M, Thijs R, Salehia M, Sander J. Seizures as a clinical manifestation in somatic autoimmune disorders. Seizure 2018; 64: 59-64.

Andrade RM, Alarcon GS, Gonzalez LA, Fernandez M, Apte M, Vila LM, et al. Seizures in patients with systemic lupus erythematosus: data from LUMINA, a multiethnic cohort (LUMINA LIV). Ann Rheum Dis 2008; 67(6): 829-34.

Appenzeller S, Cendes F, Costallat LT. Epileptic seizures in systemic lupus erythematosus. Neurology 2004; 63(10): 1808-12.

Arino H, Armangue T, Petit-Pedrol M, Sabater L, Martinez-Hernandez E, Hara M, et al. AntiLGI1-associated cognitive impairment: Presentation and long-term outcome. Neurology 2016; 87(8): 759-65.

Aronica E, Crino PB. Epilepsy related to developmental tumors and malformations of cortical development. Neurotherapeutics : the journal of the American Society for Experimental NeuroTherapeutics 2014; 11(2): 251-68.

Arroyo HA, De Rosa S, Ruggieri V, de Davila MT, Fejerman N. Epilepsy, occipital calcifications, and oligosymptomatic celiac disease in childhood. J Child Neurol 2002; 17(11): 800-6.

Asconape JJ. Pharmacokinetic Considerations with the Use of Antiepileptic Drugs in Patients with HIV and Organ Transplants. Curr Neurol Neurosci Rep 2018; 18(12): 89.

Balu R, McCracken L, Lancaster E, Graus F, Dalmau J, Titulaer MJ. A score that predicts 1-year functional status in patients with anti-NMDA receptor encephalitis. Neurology 2019; 92(3): e244-e52.

Barile-Fabris L, Hernandez-Cabrera MF, Barragan-Garfias JA. Vasculitis in systemic lupus erythematosus. Curr Rheumatol Rep 2014; 16(9): 440.

Bartynski WS, Tan HP, Boardman JF, Shapiro R, Marsh JW. Posterior reversible encephalopathy syndrome after solid organ transplantation. AJNR Am J Neuroradiol 2008; 29(5): 924-30.

Bauer J, Bien CG. Neuropathology of autoimmune encephalitides. Handbook of clinical neurology 2016; 133: 107-20.

Baumgartner A, Rauer S, Mader I, Meyer PT. Cerebral FDG-PET and MRI findings in autoimmune limbic encephalitis: correlation with autoantibody types. J Neurol 2013; 260(11): 2744-53.

Baysal-Kirac L, Tuzun E, Erdag E, Ulusoy C, Vanli-Yavuz EN, Ekizoglu E, et al. Neuronal autoantibodies in epilepsy patients with peri-ictal autonomic findings. Journal of neurology 2016; 263(3): 455-66.

Beghi E, Carpio A, Forsgren L, Hesdorffer DC, Malmgren K, Sander JW, et al.

Recommendation for a definition of acute symptomatic seizure. Epilepsia 2010; 51(4): 671-5. Ben-Or O, Zelnik N, Shaoul R, Pacht A, Lerner A. The neurologic profile of children and adolescents with inflammatory bowel disease. J Child Neurol 2015; 30(5): 551-7.

Benavente L, Morís G. Neurologic disorders associated with inflammatory bowel disease. European Journal of Neurology 2011; 18(1): 138-43. 
Bhatia S, Schmitt SE. Treating Immune-Related Epilepsy. Curr Neurol Neurosci Rep 2018; 18(3): 10.

Bien CG, Holtkamp M. "Autoimmune Epilepsy": Encephalitis With Autoantibodies for Epileptologists. Epilepsy Currents 2017; 17(3): 134-41.

Binks S, Varley J, Lee W, Makuch M, Elliott K, Gelfand JM, et al. Distinct HLA associations of LGI1 and CASPR2-antibody diseases. Brain 2018; 141(8): 2263-71.

Bonaz B, Sinniger V, Pellissier S. The Vagus Nerve in the Neuro-Immune Axis: Implications in the Pathology of the Gastrointestinal Tract. Front Immunol 2017; 8: 1452.

Borusiak P, Bettendorf U, Wiegand G, Bast T, Kluger G, Philippi H, et al. Autoantibodies to neuronal antigens in children with focal epilepsy and no prima facie signs of encephalitis. Eur $\mathbf{J}$ Paediatr Neurol 2016; 20(4): 573-9.

Boscolo S, Lorenzon A, Sblattero D, Florian F, Stebel M, Marzari R, et al. Anti transglutaminase antibodies cause ataxia in mice. PLoS One 2010; 5(3): e9698.

Brenner T, Sills GJ, Hart Y, Howell S, Waters P, Brodie MJ, et al. Prevalence of neurologic autoantibodies in cohorts of patients with new and established epilepsy. Epilepsia 2013; 54(6): 1028-35.

Britton J. Autoimmune epilepsy. Handbook of clinical neurology 2016; 133: 219-45.

Bürk K, Farecki M-L, Lamprecht G, Roth G, Decker P, Weller M, et al. Neurological symptoms in patients with biopsy proven celiac disease. Movement Disorders 2009; 24(16): 2358-62.

Cameron FJ, Northam EA, Ryan CM. The effect of type 1 diabetes on the developing brain. The Lancet Child \& adolescent health 2019.

Cameron FJ, Scratch SE, Nadebaum C, Northam EA, Koves I, Jennings J, et al. Neurological consequences of diabetic ketoacidosis at initial presentation of type 1 diabetes in a prospective cohort study of children. Diabetes care 2014; 37(6): 1554-62.

Cantarín-Extremera V, Jiménez-Legido M, Duat-Rodríguez A, García-Fernández M, OrtizCabrera NV, Ruiz-Falcó-Rojas ML, et al. Tocilizumab in pediatric refractory status epilepticus and acute epilepsy: Experience in two patients. J Neuroimmunol 2020; 340: 577142.

Carreno M, Bien CG, Asadi-Pooya AA, Sperling M, Marusic P, Elisak M, et al. Epilepsy surgery in drug resistant temporal lobe epilepsy associated with neuronal antibodies. Epilepsy Res 2017; 129: 101-5.

Chang KH, Hsu YC, Chang MY, Lin CL, Wu TN, Hwang BF, et al. A Large-Scale Study Indicates Increase in the Risk of Epilepsy in Patients With Different Risk Factors, Including Rheumatoid Arthritis. Medicine (Baltimore) 2015; 94(36): e1485.

Chapman RWL, J.M.; Colin-Jones, D.; Eade, O.E.; Smith, C.L. Increased prevalence of epilepsy in coeliac disease. BMJ 1978; 2(6132): 250-1.

Chen S, Hu J, Xu L, Brandon D, Yu J, Zhang J. Posterior Reversible Encephalopathy Syndrome After Transplantation: a Review. Mol Neurobiol 2016; 53(10): 6897-909.

Chou IC, Wang CH, Lin WD, Tsai FJ, Lin CC, Kao CH. Risk of epilepsy in type 1 diabetes mellitus: a population-based cohort study. Diabetologia 2016; 59(6): 1196-203.

Cronin CC, Jackson LM, Feighery C, Shanahan F, Abuzakouk M, Ryder DQ, et al. Coeliac disease and epilepsy. Qjm 1998; 91(4): 303-8.

Dafoulas GE, Toulis KA, McCorry D, Kumarendran B, Thomas GN, Willis BH, et al. Type 1 diabetes mellitus and risk of incident epilepsy: a population-based, open-cohort study.

Diabetologia 2017; 60(2): 258-61. 
Dai AI, Akcali A, Varan C, Demiryurek AT. Prevalence of resistant occipital lobe epilepsy associated with celiac disease in children. Child's nervous system : ChNS : official journal of the International Society for Pediatric Neurosurgery 2014; 30(6): 1091-8.

Dalgic B, Dursun I, Serdaroglu A, Dursun A. Latent and potential celiac disease in epileptic Turkish children. J Child Neurol 2006; 21(1): 6-7.

Dalmau J, Graus F. Antibody-Mediated Encephalitis. The New England journal of medicine 2018; 378(9): 840-51.

de Bruijn M, Thijs R, Majoie M, Rouhl R, van Asseldon T, van Donselaar C, et al. Neuronal antibodies in a prospective, multicenter cohort of patients with focal epilepsy

of unknown origin. American Academy of Neurology; 2019a; 2019a.

de Bruijn M, van Sonderen A, van Coevorden-Hameete MH, Bastiaansen AEM, Schreurs MWJ, Rouhl RPW, et al. Evaluation of seizure treatment in anti-LGI1, anti-NMDAR, and antiGABABR encephalitis. Neurology 2019b; 92(19): e2185-e96.

de Ferranti SD, de Boer IH, Fonseca V, Fox CS, Golden SH, Lavie CJ, et al. Type 1 diabetes mellitus and cardiovascular disease: a scientific statement from the American Heart Association and American Diabetes Association. Diabetes care 2014; 37(10): 2843-63.

DeGiorgio LA, Konstantinov KN, Lee SC, Hardin JA, Volpe BT, Diamond B. A subset of lupus anti-DNA antibodies cross-reacts with the NR2 glutamate receptor in systemic lupus erythematosus. Nat Med 2001; 7(11): 1189-93.

DeSena AD, Do T, Schulert GS. Systemic autoinflammation with intractable epilepsy managed with interleukin-1 blockade. J Neuroinflammation 2018; 15(1): 38.

Devinsky O, Schein A, Najjar S. Epilepsy associated with systemic autoimmune disorders. Epilepsy Curr 2013; 13(2): 62-8.

Diamond ML, Ritter AC, Failla MD, Boles JA, Conley YP, Kochanek PM, et al. IL-1beta associations with posttraumatic epilepsy development: a genetics and biomarker cohort study. Epilepsia 2014; 55(7): 1109-19.

Dilena R, Mauri E, Aronica E, Bernasconi P, Bana C, Cappelletti C, et al. Therapeutic effect of Anakinra in the relapsing chronic phase of febrile infection-related epilepsy syndrome. Epilepsia open 2019; 4(2): 344-50.

DiMeglio LA, Evans-Molina C, Oram RA. Type 1 diabetes. Lancet 2018; 391(10138): 2449-62. Dubey D, Alqallaf A, Hays R, Freeman M, Chen K, Ding K, et al. Neurological Autoantibody Prevalence in Epilepsy of Unknown Etiology. JAMA Neurol 2017; 74(4): 397-402. Dubey D, Britton J, McKeon A, Gadoth A, Zekeridou A, Lopez Chiriboga SA, et al. Randomized Placebo-Controlled Trial of Intravenous Immunoglobulin in Autoimmune LGI1/CASPR2 Epilepsy. Ann Neurol 2020; 87(2): 313-23.

Duong L, Klitten LL, Moller RS, Ingason A, Jakobsen KD, Skjodt C, et al. Mutations in NRXN1 in a family multiply affected with brain disorders: NRXN1 mutations and brain disorders. American journal of medical genetics Part B, Neuropsychiatric genetics : the official publication of the International Society of Psychiatric Genetics 2012; 159b(3): 354-8.

Dutra LA, Braga-Neto P, Pedroso JL, Guedes Bde V, de Souza LT, Goncalves CR, et al. Epilepsy and Behcet's disease: cortical and hippocampal involvement in Brazilian patients. J Neurol Sci 2011; 309(1-2): 1-4.

Elsehety A, Bertorini TE. Neurologic and neuropsychiatric complications of Crohn's disease. Southern medical journal 1997; 90(6): 606-10. 
Fazeli Farsani S, Souverein PC, van der Vorst MM, Knibbe CA, de Boer A, Mantel-Teeuwisse AK. Chronic comorbidities in children with type 1 diabetes: a population-based cohort study. Archives of disease in childhood 2015; 100(8): 763-8.

Finke C, Pruss H, Heine J, Reuter S, Kopp UA, Wegner F, et al. Evaluation of Cognitive Deficits and Structural Hippocampal Damage in Encephalitis With Leucine-Rich, Glioma-Inactivated 1 Antibodies. JAMA Neurol 2017; 74(1): 50-9.

Fisher RS, van Emde Boas W, Blume W, Elger C, Genton P, Lee P, et al. Epileptic seizures and epilepsy: definitions proposed by the International League Against Epilepsy (ILAE) and the International Bureau for Epilepsy (IBE). Epilepsia 2005; 46(4): 470-2.

Fleetwood T, Cantello R, Comi C. Antiphospholipid Syndrome and the Neurologist: From Pathogenesis to Therapy. Frontiers in neurology 2018; 9: 1001.

Frenkel B, White W, Tuckermann J. Glucocorticoid-Induced Osteoporosis. Advances in experimental medicine and biology 2015; 872: 179-215.

Frier BM. Hypoglycaemia in diabetes mellitus: epidemiology and clinical implications. Nature reviews Endocrinology 2014; 10(12): 711-22.

Frohlich E, Wahl R. Thyroid Autoimmunity: Role of Anti-thyroid Antibodies in Thyroid and Extra-Thyroidal Diseases. Front Immunol 2017; 8: 521.

Gadoth A, Pittock SJ, Dubey D, McKeon A, Britton JW, Schmeling JE, et al. Expanded phenotypes and outcomes among 256 LGI1/CASPR2-IgG-positive patients. Ann Neurol 2017; 82(1): 79-92.

Ganelin-Cohen E, Modan-Moses D, Hemi R, Kanety H, Ben-Zeev B, Hampe CS. Epilepsy and behavioral changes, type 1 diabetes mellitus and a high titer of glutamic acid decarboxylase antibodies. Pediatric diabetes 2016; 17(8): 617-22.

Gaspard N, Foreman BP, Alvarez V, Cabrera Kang C, Probasco JC, Jongeling AC, et al. Newonset refractory status epilepticus: Etiology, clinical features, and outcome. Neurology 2015; 85(18): 1604-13.

Gerlach AT, Thomas S, Stawicki SP, Whitmill ML, Steinberg SM, Cook CH. Vitamin B6 deficiency: a potential cause of refractory seizures in adults. JPEN Journal of parenteral and enteral nutrition 2011; 35(2): 272-5.

Gillinder L, Tjoa L, Mantzioris B, Blum S, Dionisio S. Refractory chronic epilepsy associated with neuronal auto-antibodies: could perisylvian semiology be a clue? Epileptic disorders : international epilepsy journal with videotape 2017; 19(4): 439-49.

Giordano L, Valotti M, Bosetti A, Accorsi P, Caimi L, Imberti L. Celiac disease-related antibodies in Italian children with epilepsy. Pediatr Neurol 2009; 41(1): 34-6.

Glaser N, Ngo C, Anderson S, Yuen N, Trifu A, O'Donnell M. Effects of hyperglycemia and effects of ketosis on cerebral perfusion, cerebral water distribution, and cerebral metabolism. Diabetes 2012; 61(7): 1831-7.

Gobbi G. Coeliac disease, epilepsy and cerebral calcifications. Brain and Development 2005; 27(3): 189-200.

Gobbi G, Bouquet F, Greco L, Lambertini A, Tassinari CA, Ventura A, et al. Coeliac disease, epilepsy, and cerebral calcifications. The Italian Working Group on Coeliac Disease and Epilepsy. Lancet (London, England) 1992; 340(8817): 439-43.

Gonzalez-Duarte A, Cantu-Brito CG, Ruano-Calderon L, Garcia-Ramos G. Clinical description of seizures in patients with systemic lupus erythematosus. Eur Neurol 2008; 59(6): 320-3.

Graus F, Titulaer MJ, Balu R, Benseler S, Bien CG, Cellucci T, et al. A clinical approach to diagnosis of autoimmune encephalitis. The Lancet Neurology 2016; 15(4): 391-404. 
Gresa-Arribas N, Arino H, Martinez-Hernandez E, Petit-Pedrol M, Sabater L, Saiz A, et al. Antibodies to inhibitory synaptic proteins in neurological syndromes associated with glutamic acid decarboxylase autoimmunity. PLoS One 2015; 10(3): e0121364.

Hackert JK, Muller L, Rohde M, Bien CG, Kohling R, Kirschstein T. Anti-GAD65 Containing Cerebrospinal Fluid Does not Alter GABAergic Transmission. Frontiers in cellular neuroscience 2016; 10: 130.

Hanly JG, Fisk JD, McCurdy G, Fougere L, Douglas JA. Neuropsychiatric syndromes in patients with systemic lupus erythematosus and rheumatoid arthritis. J Rheumatol 2005; 32(8): 1459-6. Hanly JG, Stassen W, Whelton M, Callaghan N. Epilepsy and coeliac disease. J Neurol Neurosurg Psychiatry 1982; 45(8): 729-30.

Hanly JG, Urowitz MB, Su L, Gordon C, Bae S-C, Sanchez-Guerrero J, et al. Seizure disorders in systemic lupus erythematosus results from an international, prospective, inception cohort study. Annals of the Rheumatic Diseases 2012a; 71(9): 1502-9.

Hanly JG, Urowitz MB, Su L, Gordon C, Bae SC, Sanchez-Guerrero J, et al. Seizure disorders in systemic lupus erythematosus results from an international, prospective, inception cohort study. Ann Rheum Dis 2012b; 71(9): 1502-9.

Harboe E, Tjensvoll AB, Maroni S, Goransson LG, Greve OJ, Beyer MK, et al. Neuropsychiatric syndromes in patients with systemic lupus erythematosus and primary Sjogren syndrome: a comparative population-based study. Ann Rheum Dis 2009; 68(10): 1541-6.

Herranz MT, Rivier G, Khamashta MA, Blaser KU, Hughes GR. Association between antiphospholipid antibodies and epilepsy in patients with systemic lupus erythematosus. Arthritis and rheumatism 1994; 37(4): 568-71.

ILAE Consortium on Complex Epilepsies. Genome-wide mega-analysis identifies 16 loci and highlights diverse biological mechanisms in the common epilepsies. Nat Commun 2018; 9(1): 5269.

Islam MA, Alam F, Cavestro C, Calcii C, Sasongko TH, Levy RA, et al. Antiphospholipid antibodies in epilepsy: A systematic review and meta-analysis. Autoimmunity reviews 2018; 17(8): 755-67.

Jette N, Amoozegar F, Patten SB. Depression in epilepsy, migraine, and multiple sclerosis: Epidemiology and how to screen for it. Neurology Clinical practice 2017; 7(2): 118-27.

Julian T, Hadjivassiliou M, Zis P. Gluten sensitivity and epilepsy: a systematic review. Journal of neurology 2018.

Jun JS, Lee ST, Kim R, Chu K, Lee SK. Tocilizumab treatment for new onset refractory status epilepticus. Ann Neurol 2018; 84(6): 940-5.

Karaaslan Z, Ekizoglu E, Tekturk P, Erdag E, Tuzun E, Bebek N, et al. Investigation of neuronal auto-antibodies in systemic lupus erythematosus patients with epilepsy. Epilepsy Res 2017; 129: 132-7.

Keezer MR, Novy J, Sander JW. Type 1 diabetes mellitus in people with pharmacoresistant epilepsy: Prevalence and clinical characteristics. Epilepsy Res 2015; 115: 55-7.

Keezer MR, Sisodiya SM, Sander JW. Comorbidities of epilepsy: current concepts and future perspectives. The Lancet Neurology 2016a; 15(1): 106-15.

Keezer MR, Sisodiya SM, Sander JW. Comorbidities of epilepsy: current concepts and future perspectives. Lancet Neurology 2016b; 15(1): 106-15.

Kenney-Jung DL, Vezzani A, Kahoud RJ, LaFrance-Corey RG, Ho ML, Muskardin TW, et al. Febrile infection-related epilepsy syndrome treated with anakinra. Ann Neurol 2016; 80(6): 93945. 
Kenny JR, Liu MM, Chow AT, Earp JC, Evers R, Slatter JG, et al. Therapeutic protein drugdrug interactions: navigating the knowledge gaps-highlights from the 2012 AAPS NBC Roundtable and IQ Consortium/FDA workshop. The AAPS journal 2013; 15(4): 933-40. Kieslich M, Errazuriz G, Posselt HG, Moeller-Hartmann W, Zanella F, Boehles H. Brain whitematter lesions in celiac disease: a prospective study of 75 diet-treated patients. Pediatrics 2001; 108(2): E21.

Kim SY, Senatorov VV, Jr., Morrissey CS, Lippmann K, Vazquez O, Milikovsky DZ, et al. TGFbeta signaling is associated with changes in inflammatory gene expression and perineuronal net degradation around inhibitory neurons following various neurological insults. Scientific reports $2017 \mathrm{a} ; 7(1)$ : 7711 .

Kim TJ, Lee ST, Moon J, Sunwoo JS, Byun JI, Lim JA, et al. Anti-LGI1 encephalitis is associated with unique HLA subtypes. Ann Neurol 2017b; 81(2): 183-92.

Kohoutova D, Moravkova P, Kruzliak P, Bures J. Thromboembolic complications in inflammatory bowel disease. Journal of thrombosis and thrombolysis 2015; 39(4): 489-98. Kurien M, Ludvigsson JF, Sanders DS, Zylberberg HM, Green PH, Sundelin HEK, et al. Persistent mucosal damage and risk of epilepsy in people with celiac disease. Eur J Neurol 2018; 25(3): 592-e38.

Kutlu G, Semercioglu S, Ucler S, Erdal A, Inan LE. Epileptic seizures in Neuro-Behcet disease: why some patients develop seizure and others not? Seizure 2015; 26: 32-5.

Labate A, Gambardella A, Messina D, Tammaro S, Le Piane E, Pirritano D, et al. Silent celiac disease in patients with childhood localization-related epilepsies. Epilepsia 2001; 42(9): 1153-5. Lagarde S, Villeneuve N, Trebuchon A, Kaphan E, Lepine A, McGonigal A, et al. Anti-tumor necrosis factor alpha therapy (adalimumab) in Rasmussen's encephalitis: An open pilot study. Epilepsia 2016; 57(6): 956-66.

Laurent C, Capron J, Quillerou B, Thomas G, Alamowitch S, Fain O, et al. Steroid-responsive encephalopathy associated with autoimmune thyroiditis (SREAT): Characteristics, treatment and outcome in 251 cases from the literature. Autoimmunity reviews 2016; 15(12): 1129-33. Lebwohl B, Sanders DS, Green PHR. Coeliac disease. Lancet 2018; 391(10115): 70-81. Lee WJ, Lee ST, Byun JI, Sunwoo JS, Kim TJ, Lim JA, et al. Rituximab treatment for autoimmune limbic encephalitis in an institutional cohort. Neurology 2016; 86(18): 1683-91. Leypoldt F, de Witte L, Lancaster E, Titulaer MJ. Serum neuronal cell-surface antibodies in firstepisode psychosis. The lancet Psychiatry 2017; 4(3): 186-7.

Lisnevskaia L, Murphy G, Isenberg D. Systemic lupus erythematosus. Lancet 2014; 384(9957): 1878-88.

Litmeier S, Prüss H, Witsch E, Witsch J. Initial serum thyroid peroxidase antibodies and longterm outcomes in SREAT. Acta Neurol Scand 2016; 134(6): 452-7.

Lossos A, River Y, Eliakim A, Steiner I. Neurologic Aspects of Inflammatory Bowel Disease. Neurology 1995; 45(3): 416-21.

Ludvigsson JF, Zingone F, Tomson T, Ekbom A, Ciacci C. Increased risk of epilepsy in biopsyverified celiac disease: A population-based cohort study. Neurology 2012a; 78(18): 1401-7. Ludvigsson JF, Zingone F, Tomson T, Ekbom A, Ciacci C. Increased risk of epilepsy in biopsyverified celiac disease: a population-based cohort study. Neurology 2012b; 78(18): 1401-7. Luostarinen L, Dastidar P, Collin P, Peraaho M, Maki M, Erila T, et al. Association between coeliac disease, epilepsy and brain atrophy. Eur Neurol 2001; 46(4): 187-91.

Magro-Checa C, Zirkzee EJ, Beaart-van de Voorde LJJ, Middelkoop HA, van der Wee NJ, Huisman MV, et al. Value of multidisciplinary reassessment in attribution of neuropsychiatric 
events to systemic lupus erythematosus: prospective data from the Leiden NPSLE cohort. Rheumatology (Oxford, England) 2017; 56(10): 1676-83.

Malter MP, Frisch C, Zeitler H, Surges R, Urbach H, Helmstaedter C, et al. Treatment of immune-mediated temporal lobe epilepsy with GAD antibodies. Seizure 2015; 30: 57-63. Masingue M, Benoist JF, Roze E, Moussa F, Sedel F, Lubetzki C, et al. Cerebral folate deficiency in adults: A heterogeneous potentially treatable condition. J Neurol Sci 2019; 396: $112-8$.

Mastrangelo M, Tromba V, Silvestri F, Costantino F. Epilepsy in children with type 1 diabetes mellitus: Pathophysiological basis and clinical hallmarks. Eur J Paediatr Neurol 2019; 23(2): 240-7.

Mavroudi A, Xinias I, Papastavrou T, Karatza E, Fotoulaki M, Panteliadis C, et al. Increased prevalence of silent celiac disease among Greek epileptic children. Pediatr Neurol 2007; 36(3): $165-9$.

McCorry D, Nicolson A, Smith D, Marson A, Feltbower RG, Chadwick DW. An association between type 1 diabetes and idiopathic generalized epilepsy. Ann Neurol 2006; 59(1): 204-6. Meneses G, Bautista M, Florentino A, Diaz G, Acero G, Besedovsky H, et al. Electric stimulation of the vagus nerve reduced mouse neuroinflammation induced by lipopolysaccharide. Journal of inflammation (London, England) 2016; 13: 33. Mikdashi J, Krumholz A, Handwerger B. Factors at diagnosis predict subsequent occurrence of seizures in systemic lupus erythematosus. Neurology 2005; 64(12): 2102-7.

Miller TD, Chong TT, Aimola Davies AM, Ng TWC, Johnson MR, Irani SR, et al. Focal CA3 hippocampal subfield atrophy following LGI1 VGKC-complex antibody limbic encephalitis. Brain 2017; 140(5): 1212-9.

Mitoma H, Manto M, Hampe CS. Pathogenic Roles of Glutamic Acid Decarboxylase 65 Autoantibodies in Cerebellar Ataxias. Journal of immunology research 2017; 2017: 2913297. Miyakis S, Lockshin MD, Atsumi T, Branch DW, Brey RL, Cervera R, et al. International consensus statement on an update of the classification criteria for definite antiphospholipid syndrome (APS). Journal of thrombosis and haemostasis : JTH 2006; 4(2): 295-306. Montagna G, Imperiali M, Agazzi P, D'Aurizio F, Tozzoli R, Feldt-Rasmussen U, et al. Hashimoto's encephalopathy: A rare proteiform disorder. Autoimmunity reviews 2016; 15(5): 466-76.

Moreira I, Teixeira F, Martins Silva A, Vasconcelos C, Farinha F, Santos E. Frequent involvement of central nervous system in primary Sjogren syndrome. Rheumatology International 2014; 35(2): 289-94.

Mueller SH, Farber A, Pruss H, Melzer N, Golombeck KS, Kumpfel T, et al. Genetic predisposition in anti-LGI1 and anti-NMDA receptor encephalitis. Ann Neurol 2018; 83(4): 8639.

Muñoz-Lopetegi A, de Bruijn M, Boukhrissi S, Bastiaansen AEM, Nagtzaam MMP, Hulsenboom ESP, et al. Neurologic syndromes related to anti-GAD65: Clinical and serologic response to treatment. Neurol Neuroimmunol Neuroinflamm 2020; 7(3).

NINDS. 2014 NINDS Benchmarks for Epilepsy Research. 2014 [cited 2019 January 15]; Available from: https://www.ninds.nih.gov/About-NINDS/Strategic-Plans-Evaluations/StrategicPlans/2014-NINDS-Benchmarks-Epilepsy-Research

Nobrega-Jr AW, Gregory CP, Schlindwein-Zanini R, Neves FS, Wolf P, Walz R, et al. Mesial temporal lobe epilepsy with hippocampal sclerosis is infrequently associated with neuronal autoantibodies. Epilepsia 2018; 59(9): e152-e6. 
Nyuyki KD, Pittman QJ. Toward a better understanding of the central consequences of intestinal inflammation. Ann N Y Acad Sci 2015; 1351: 149-54.

O'Connell MA, Harvey AS, Mackay MT, Cameron FJ. Does epilepsy occur more frequently in children with Type 1 diabetes? Journal of paediatrics and child health 2008; 44(10): 586-9. O'Toole KK, Hooper A, Wakefield S, Maguire J. Seizure-induced disinhibition of the HPA axis increases seizure susceptibility. Epilepsy Res 2014; 108(1): 29-43.

Ohkawa T, Fukata Y, Yamasaki M, Miyazaki T, Yokoi N, Takashima H, et al. Autoantibodies to epilepsy-related LGI1 in limbic encephalitis neutralize LGI1-ADAM22 interaction and reduce synaptic AMPA receptors. J Neurosci 2013; 33(46): 18161-74.

Oliveira GR, Teles BC, Brasil EF, Souza MH, Furtado LE, de Castro-Costa CM, et al. Peripheral neuropathy and neurological disorders in an unselected Brazilian population-based cohort of IBD patients. Inflammatory bowel diseases 2008; 14(3): 389-95.

Olson CA, Vuong HE, Yano JM, Liang QY, Nusbaum DJ, Hsiao EY. The Gut Microbiota Mediates the Anti-Seizure Effects of the Ketogenic Diet. Cell 2018; 173(7): 1728-41.e13. Ong M, Kohane IS, Cai T, Gorman MP, Mandl KD. Population-level evidence for an autoimmune etiology of epilepsy. JAMA Neurology 2014; 71(5): 569-74.

Pauletti A, Terrone G, Shekh-Ahmad T, Salamone A, Ravizza T, Rizzi M, et al. Targeting oxidative stress improves disease outcomes in a rat model of acquired epilepsy. Brain : a journal of neurology 2017; 140(7): 1885-99.

Peltola M, Kaukinen K, Dastidar P, Haimila K, Partanen J, Haapala AM, et al. Hippocampal sclerosis in refractory temporal lobe epilepsy is associated with gluten sensitivity. J Neurol Neurosurg Psychiatry 2009; 80(6): 626-30.

Pengiran Tengah DS, Holmes GK, Wills AJ. The prevalence of epilepsy in patients with celiac disease. Epilepsia 2004; 45(10): 1291-3.

Perucca P, Gilliam FG. Adverse effects of antiepileptic drugs. The Lancet Neurology 2012; 11(9): 792-802.

Pineda E, Shin D, You SJ, Auvin S, Sankar R, Mazarati A. Maternal immune activation promotes hippocampal kindling epileptogenesis in mice. Ann Neurol 2013; 74(1): 11-9.

Pitkanen A, Roivainen R, Lukasiuk K. Development of epilepsy after ischaemic stroke. The Lancet Neurology 2016; 15(2): 185-97.

Planaguma J, Haselmann H, Mannara F, Petit-Pedrol M, Grunewald B, Aguilar E, et al. EphrinB2 prevents N-methyl-D-aspartate receptor antibody effects on memory and neuroplasticity. Ann Neurol 2016; 80(3): 388-400.

Poulton CJ, Schot R, Kia SK, Jones M, Verheijen FW, Venselaar H, et al. Microcephaly with simplified gyration, epilepsy, and infantile diabetes linked to inappropriate apoptosis of neural progenitors. American journal of human genetics 2011; 89(2): 265-76.

Quek AL, Britton JW, McKeon A, et al. Autoimmune epilepsy: Clinical characteristics and response to immunotherapy. Archives of Neurology 2012; 69(5): 582-93.

Ramakrishnan R, Appleton R. Study of prevalence of epilepsy in children with type 1 diabetes mellitus. Seizure 2012; 21(4): 292-4.

Ramsey-Goldman R, Alarcon GS, McGwin G, Petri M, Vila LM, Edberg JC, et al. Time to seizure occurrence and damage in PROFILE, a multi-ethnic systemic lupus erythematosus cohort. Lupus 2008; 17(3): 177-84.

Ranua J, Luoma K, Auvinen A, Maki M, Haapala AM, Peltola J, et al. Celiac disease-related antibodies in an epilepsy cohort and matched reference population. Epilepsy Behav 2005; 6(3): 388-92. 
Rom AL, Wu CS, Olsen J, Jawaheer D, Hetland ML, Christensen J, et al. Parental rheumatoid arthritis and childhood epilepsy: A nationwide cohort study. Neurology 2016; 87(24): 2510-6. Roseti C, van Vliet EA, Cifelli P, Ruffolo G, Baayen JC, Di Castro MA, et al. GABAA currents are decreased by IL-1beta in epileptogenic tissue of patients with temporal lobe epilepsy: implications for ictogenesis. Neurobiology of disease 2015; 82: 311-20.

Ruggieri M, Incorpora G, Polizzi A, Parano E, Spina M, Pavone P. Low prevalence of neurologic and psychiatric manifestations in children with gluten sensitivity. The Journal of pediatrics 2008; 152(2): 244-9.

Sa M, Singh R, Pujar S, D'Arco F, Desai N, Eltze C, et al. Centromedian thalamic nuclei deep brain stimulation and Anakinra treatment for FIRES - Two different outcomes. European journal of paediatric neurology : EJPN : official journal of the European Paediatric Neurology Society 2019.

Sanna G, Bertolaccini ML, Cuadrado MJ, Laing H, Khamashta MA, Mathieu A, et al. Neuropsychiatric manifestations in systemic lupus erythematosus: prevalence and association with antiphospholipid antibodies. J Rheumatol 2003; 30(5): 985-92.

Schober E, Otto KP, Dost A, Jorch N, Holl R. Association of epilepsy and type 1 diabetes mellitus in children and adolescents: is there an increased risk for diabetic ketoacidosis? The Journal of pediatrics 2012; 160(4): 662-6.e1.

Schulze-Bonhage A, Kurthen M, Walger P, Elger CE. Pharmacorefractory status epilepticus due to low vitamin B6 levels during pregnancy. Epilepsia 2004; 45(1): 81-4.

Sillanpaa M, Saarinen MM, Ronnemaa T, Gissler M, Schmidt D. Overrepresentation of epilepsy in children with type 1 diabetes is declining in a longitudinal population study in Finland. Acta paediatrica (Oslo, Norway : 1992) 2019: e14910.

Sonneville R, Magalhaes E, Meyfroidt G. Central nervous system infections in immunocompromised patients. Current opinion in critical care 2017; 23(2): 128-33.

Steriade C, Moosa ANV, Hantus S, Prayson RA, Alexopoulos A, Rae-Grant A. Electroclinical features of seizures associated with autoimmune encephalitis. Seizure 2018; 60: 198-204. Steup-Beekman GM, Zirkzee EJ, Cohen D, Gahrmann BM, Emmer BJ, Steens SC, et al. Neuropsychiatric manifestations in patients with systemic lupus erythematosus: epidemiology and radiology pointing to an immune-mediated cause. Ann Rheum Dis 2013; 72 Suppl 2: ii76-9. Suh SW, Fan Y, Hong SM, Liu Z, Matsumori Y, Weinstein PR, et al. Hypoglycemia induces transient neurogenesis and subsequent progenitor cell loss in the rat hippocampus. Diabetes 2005; 54(2): 500-9.

Thijs RD, Surges R, O'Brien TJ, Sander JW. Epilepsy in adults. Lancet 2019; 393(10172): 689701.

Thompson J, Bi M, Murchison AG, Makuch M, Bien CG, Chu K, et al. The importance of early immunotherapy in patients with faciobrachial dystonic seizures. Brain 2018; 141(2): 348-56. Titulaer MJ, McCracken L, Gabilondo I, Armangue T, Glaser C, Iizuka T, et al. Treatment and prognostic factors for long-term outcome in patients with anti-NMDA receptor encephalitis: an observational cohort study. The Lancet Neurology 2013a; 12(2): 157-65.

Titulaer MJ, McCracken L, Gabilondo I, Armangué T, Glaser C, Iizuka T, et al. Treatment and prognostic factors for long-term outcome in patients with anti-NMDA receptor encephalitis: an observational cohort study. The Lancet Neurology 2013b; 12(2): 157-65.

Toledano M, Britton JW, McKeon A, Shin C, Lennon VA, Quek AM, et al. Utility of an immunotherapy trial in evaluating patients with presumed autoimmune epilepsy. Neurology 2014; 82(18): 1578-86. 
Tomson T, Battino D, Bonizzoni E, Craig J, Lindhout D, Perucca E, et al. Comparative risk of major congenital malformations with eight different antiepileptic drugs: a prospective cohort study of the EURAP registry. The Lancet Neurology 2018; 17(6): 530-8.

Tong F, Zou Y, Liang Y, Lei H, Lopsong T, Liu Y, et al. The Water Diffusion of Brain Following Hypoglycemia in Rats - A Study with Diffusion Weighted Imaging and Neuropathologic Analysis. Neuroscience 2019; 409: 58-68.

Toyota T, Akamatsu N, Tanaka A, Shouzaki T, Tsuji S, Saito K, et al. Mesial temporal lobe epilepsy as a neuropsychiatric syndrome of systemic lupus erythematosus. Epilepsia 2013; 54(3): e33-6.

Tsai J-DL, Cheng-Li; Lin, Cheng-Chieh; Sung Fung-Chang; Lue, Ko-Huang. Risk of epilepsy in patients with systemic lupus erythematosus - a retrospective cohort study. Neuropsychiatr Dis Treat 2014; 10: 1635-43.

Vaknin A, Eliakim R, Ackerman Z, Steiner I. Neurological abnormalities associated with celiac disease. J Neurol 2004; 251(11): 1393-7.

van Sonderen A, Roelen DL, Stoop JA, Verdijk RM, Haasnoot GW, Thijs RD, et al. Anti-LGI1 encephalitis is strongly associated with HLA-DR7 and HLA-DRB4. Ann Neurol 2017; 81(2): 193-8.

Varadkar S, Bien CG, Kruse CA, Jensen FE, Bauer J, Pardo CA, et al. Rasmussen's encephalitis: clinical features, pathobiology, and treatment advances. Lancet Neurology 2014; 13(2): 195-205. Vezzani A, Balosso S, Ravizza T. Neuroinflammatory pathways as treatment targets and biomarkers in epilepsy. Nat Rev Neurol 2019; 15(8): 459-72.

Virta LJ, Kolho KL. The risk of contracting pediatric inflammatory bowel disease in children with celiac disease, epilepsy, juvenile arthritis and type 1 diabetes--a nationwide study. Journal of Crohn's \& colitis 2013; 7(1): 53-7.

Vogrig A, Joubert B, Andre-Obadia N, Gigli GL, Rheims S, Honnorat J. Seizure specificities in patients with antibody-mediated autoimmune encephalitis. Epilepsia 2019; 60(8): 1508-25.

Watad A, Tiosano S, Bragazzi NL, Brigo F, Comaneshter D, Cohen AD, et al. Epilepsy among Systemic Lupus Erythematosus Patients: Insights from a Large Database Analysis.

Neuroepidemiology 2018; 50(1-2): 1-6.

Wright S, Geerts AT, Jol-van der Zijde CM, Jacobson L, Lang B, Waters P, et al. Neuronal antibodies in pediatric epilepsy: Clinical features and long-term outcomes of a historical cohort not treated with immunotherapy. Epilepsia 2016; 57(5): 823-31.

Yang Y, Yuan C, Shen SQ, Wang XE, Mei QH, Jiang WQ, et al. Autoantibodies to NR2A Peptide of the Glutamate/NMDA Receptor in Patients with Seizure Disorders in Neuropsychiatric Systemic Lupus Erythematosus. Mediators of inflammation 2017; 2017: 5047898.

Yorulmaz H, Kaptan E, Seker FB, Oztas B. Type 1 diabetes exacerbates blood-brain barrier alterations during experimental epileptic seizures in an animal model. Cell biochemistry and function 2015; 33(5): 285-92.

Zelnik N, Pacht A, Obeid R, Lerner A. Range of neurologic disorders in patients with celiac disease. Pediatrics 2004; 113(6): 1672-6.

Zhang Z, Liu Q, Liu M, Wang H, Dong Y, Ji T, et al. Upregulation of HMGB1-TLR4 inflammatory pathway in focal cortical dysplasia type II. J Neuroinflammation 2018; 15(1): 27. Zila I, Mokra D, Kopincova J, Kolomaznik M, Javorka M, Calkovska A. Vagal-immune interactions involved in cholinergic anti-inflammatory pathway. Physiological research 2017; 66(Supplementum 2): S139-s45. 
Steriade et al. 2020 Systemic autoimmune disorders and epilepsy 